POLSKA AKADEMIA NAUK - ZAKEAD BADANIA SSAKÖW
A C T A
$\mathrm{T} \mathrm{H}$

VOL. VII, 11.

BIAŁOWIEŻA

$30 . \mathrm{XI} .1963$

Roman A N D R Z E J E W S K I

\title{
Processes oi Incoming, Settlement and Iisappearance of Individuals and Variations in the Numbers of Small Rodents
}

\author{
Procesy nachodzenia, osiedlania się i ubywania osobników \\ a dynamika liczebności drobnych gryzoni
}

[With 10 Figs. \& 22 Tables]

I. Introduction

II. Investigation methods 170

III. Description of the study area . . . . . . . . . . . . . 172

IV. Amount of materials collected . . . . . . . . . . . . . . 173

V. Trappability

1. Description of trappability . . . . . . . . . . . . . . 174

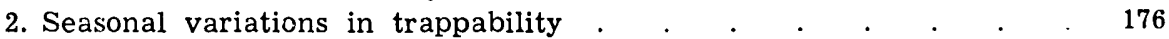

3. Trappability of an individual during the period of its stay in the study area . . . . . . . . . . . . . . . . . 179

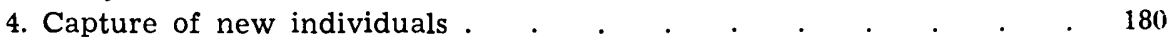

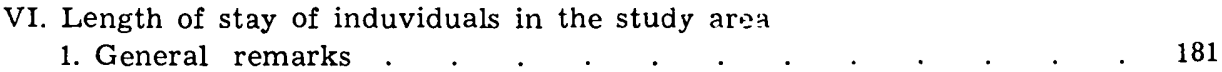

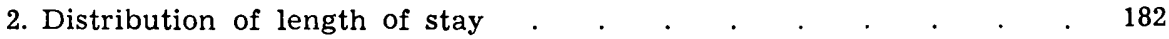

VII. Variations in numbers

1. Introductory remarks . . . . . . . . . . . . . . . 186

2. Variations in numbers during the yearly cycle . . . . . $\quad 188$

3. Variations in numbers of particular species . . . . . . . . . $\quad 192$

4. Charges in numbers of rodents . . . . . . . . . . . . $\quad . \quad 193$

viII. Exchange of individuals
1. Incoming . . . . . . . . . 195

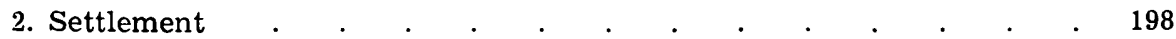

3. Disappearance . . . . . . . . . . . . . $\quad . \quad 200$

4. Rotation and variations in the degree of settledness of the population 203

IX. Summary . . . . . . . . . . . . . . . . . $\quad$. 208

References . . . . . . . . . . . . . . . . . 210

Streszczenie , . . . . . . . . . . . . 211 


\section{INTRODUCTION}

Numerous authors have shown that populations of vertebrates consists of settied and migrating animals. The first of these possess a defined area of penetration, often surrounding the place in which they live (nest, burrow etc.), the second wander about within the limits of the whole population. The connection of each individual with these two groups is not constant; a settled individual may change to being a migrating individual and vice versa. This problem has been dealt with in collective studies ( $\mathrm{K}$ a l e l a, 1954; $\mathrm{N}$ a u m ov, 1956).

Therefore, if we begin observing a section of an area occupied by a population of animals, the composition of the individuals there is subject to constant change (rotation); certain individuals come into the study area and a certain number of individuals constantly leave it ( $R$ a 11,1036 ).

This constant process of rotation is caused by: on the one hand reproduction and mortality, and on the other the migration of animals within the population (immigration into the given section of area and emigration from it).

The aim of the present study was to trace, in the defined section of the area, over a long period, the course taken by variations in the numbers of the animals and the basic causes governing these variations, that is, the processes of incoming and disappearance of individuals.

The object of our investigations was formed by thres species of rodents, predominating in numbers in the rodent fauna of the forest habitat examined, as follows: Clethrionomys glareolus (S chreber, 1780), Apodeinus agrarius (P a 11 as, 1771) and Apodemus (Sylvaemus) flavicollis (M e l ch i o r, 1834).

Acknowledgements: I have pleasure in recording my thanks, which are due to T.Wierzbowska, M.Sc., and J. Glogowska, M.Sc. for consulting with me the statistical work on the materials, and to the whole group of scientific and technical staff of the Field Station of the Institute of Ecology, Polish Academy of Sciences at Dziekanow Leśny for their help in collecting material and making calculations.

\section{INVESTIGATION METHODS}

The most suitable method for estimating the numbers, the incoming and disappearance of animals from the given area is undoubtedly the individual marking of each animal in order to be able to trace their movements. For this reason the registration of rodents living in the study area was based on capture, individual marking and release of the animals.

Forest habitats, on account of their inaccessibility fur observations and penetration by the investigator of the places in which the rodents live, present considerable obstacles to the rapid and accurate capture and marking of all the individuals. Similar difficulties, occurring when examining synanthropic rodents, were successfully overcome by teaching the animals living in the study area to make use of the attractive and suitably arranged bait ( $\mathrm{Chitty} \& \mathrm{Sh}$ or te $\mathrm{n}, 1946$; C z y ż e w s ki, 1953).

In the present investigations the research method forming a combination of bait-laying and the capture and marking of animals was used (A ndrzeje ws ki \& Pi e low s ki, 1956).

Bait was laid in places distributed in the form of a network covering the whole area. Distribution was therefore independent of the topography 
of the area, differences in the biotope, and the possible distribution of burrows, feeding grounds of the rodents etc.

The intervals between the places where bait was laid were about $14 \mathrm{~m}$. The diameter of the home ranges of the species examined is far greater than the interval used between the bait sites ( $\mathrm{N} \mathrm{a} \mathrm{u} \mathrm{mov}, 1951 ; \mathrm{N} \mathrm{i} \mathrm{ki-}$ t in a, 1958 a and b), thus ensuring that three should be bait sites in ali the home ranges of the rodents living in the study area. In this way all the individuals in the study area should be able to find and learn to visit at least one of the sites, which were given numbers and letters similarly to a chequerboard to make it easy to identify them.

Oats were used as bait, since according to data in literature, also confirmed by our own observations, they make a sufficiently attractive bait under forest conditions to be readily eaten whatever the supply of natural food (L i n n, 1954; P o n u g a y e v a, 1954).

The oats were placed once daily in portions consisting of several grains, in houses built of two or four half-bricks (thinwalled long cavity bricks) roofed by a metal plate, tile etc., or in wooden boxes with holes through which the rodents entered.

The process of finding the sites with the bait and learning to visit them lasts from 4-10 days, and the percentage of places in which the mice eat the bait depends in the first place (although not only) on the density of the mice in the given area (A ndrzejewski \& Pielowski, 1956).

The second element of registration was the capture of the animals. The rodents were caught in wooden live-traps set once a week on the bait sites, the traps being set one day in rows with odd numbers, and the next: day in rows with even numbers. The animals were twice removed from the traps - at midnight and in the morning. The traps were set in the study area about noon, and inspection made twice during the night in order to shcrten as far as possible the time spent by each individual in the trap, thus reducing to a minimum the disturbance in the course of its life.

The trap was placed by the house containing the bait, in the space left by removing one of the four half-bricks so that the doors opened into the interior of the house. In the case of the wooden boxes with bait, the trap was placed at one of the entry holes. Bait was placed in the trap only.

The rodents caught were marked on the spot by toes climbing, after which they were at once released. Mice caught which already had a number were also immediately released after the number had been read. The method of numbering adopted by $\mathrm{N}$ a u mov (1951) was used.

The area chosen for the investigations was covered by 150 sites $(15 \times 10$ rows) on which the bait was sprinkled and on which the mice were caught. This area was approximately 3 ha in extent. 
Accounts of the results of captures were made by recording on the spot the following data: place of capture (row and number of the bait site), species, number of the individual and its sex and the date and time of inspection of the trap for the whole record. The night and morning inspections made during one night were recorded under one date (morning date). In view of the poor legibility of the entries made in the area, especially when it was raining during inspection of the traps, the account was written up on collective cards for each species jointly for a whole week, and at the same time the date and place of capture of each individual were entered on its individual card, on which entries of each consecutive capture were thus recorded.

These two kinds of accounts, that is, the weekly collective cards and the card index of each number, were used later on in working out the comparisons contained in this study. The basic collective comparison was made by the "calendar of captures" method (Petrusewicz \& Andrzejewski, 1962). This comparison was used for the greater part of the work done on these materials.

Where a certain analysis of the material has been considered in yearly intervals, then the period of October 1st of one year to September 30th of the following year has been taken as forming one year.

\section{DESCRIPTION OF THE STUDY AREA}

The investigations were made on the Field Station of the Institute of Ecology of the Polish Academy of Sciences, at Dziekanów Leśny near Warsaw. The study area was situated in Section 29 of the Laski Forest Administration District of the Kampinos National Park (Kampinos Forest) ${ }^{1}$ ).

Variations in this environment of the study area were formed by two higher and drier belts, and two lower and wetter belts, situated alternately, running parallel to the narrower border of the area.

A drainage ditch, not renewed or cleaned out for a considerable time, about $1.5 \mathrm{~m}$. wide, and periodically filled with water, ran through the wetter belt situated on the border of the area.

The drier belts were covered by trees forming the Vaccinio myrtylii-Pinetum $\mathrm{Kobendza}, 1930$ association. The age of the pine trees in this association was about 50 years. The wetter belts were covered by forest forming the Carici elonyatae-Alnetum W. Koch, 1926 association. The alder stand in this association had grown from shoots from the pollarded trunk, the trees being about 45 years old.2)

The Kampinos Forest is characterised by fairly considerable amplitude of fluctuations in the level of ground water over the course of a year. With a medium, and even more so with a high level of ground water, water spreads over the surface of the ground in a large part of the alder woods, leaving only the emerged clumps of the alder trees described above. During this period the rodents can live only in these clumps. The drier woods are never flooded.

According to the measurements made by the Field Station of the Institute of Ecology, the maximum level of ground water occurs at the beginning of April, and the quickest rise in the water level is connected with the thaw period of snow and ice. The minimum level is noted in July or September.

1) The established numeration of areas of research on sodents carried out by the Field Station of the Institute of Ecology, Polish Academy of Sciences, marks this area as number I.

2) I am most grateful to $\mathrm{Dr}, \mathrm{T}, \mathrm{Tr}$ a c z y k for identifying the plant associations in the study area. 
The lower belts in the study area were partly flooded even with a medium level of water, but it was only with the highest level of ground water that it was possible to notice a decrease in the trappability of the mice in certain parts of the area. The bait sites in flooded sections were situated on clumps of alders.

The level of the ground water in the belts with the pine stand (Vaccinio myrtyliiPinetum association) in the study area was at least $50-80 \mathrm{~cm}$. lower than ground level.

\section{AMOUNT OF MATERIALS COLLECTED}

The investigations were made from Oct. 1st 1955 to Oct. 1st 1961, initial observations being continued for 30 weeks before October 1st 1955 in the study area, which made it possible to determine the characteristics of the composition of rodents in the study area on Oct. 1st 1955. After Oct. 1st 1961 observations were continued until the moment when all the individuals registered there on October 1st 1961 had disappeared from the area.

\section{Table 1.}

Amount of materials collected.

\begin{tabular}{|c|c|c|c|c|c|c|c|c|c|c|}
\hline \multirow[b]{3}{*}{ Year } & \multicolumn{2}{|c|}{ C. Blareolus } & \multicolumn{2}{|c|}{ A, agrarius } & \multicolumn{2}{|c|}{ A. Plavicollis } & \multicolumn{2}{|c|}{ Total } & \multirow{3}{*}{ 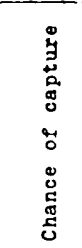 } & \multirow{3}{*}{ 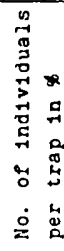 } \\
\hline & \multicolumn{8}{|c|}{ Number of: } & & \\
\hline & 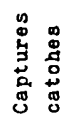 & 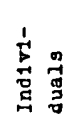 & 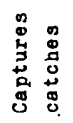 & 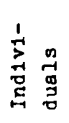 & 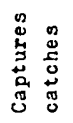 & 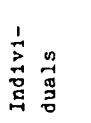 & 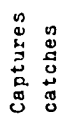 & 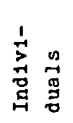 & & \\
\hline $1955 / 56$ & 2303 & 261 & 844 & 230 & 476 & 121 & 3623 & 612 & 15300 & 0.23 \\
\hline $1956 / 57$ & 891 & 203 & 594 & 323 & 163 & 53 & 1648 & 579 & 15300 & 0.11 \\
\hline $1957 / 58$ & 447 & 138 & 194 & 63 & 61 & 34 & 702 & 235 & 13800 & 0.05 \\
\hline $1958 / 59$ & 654 & 248 & 1594 & 380 & 418 & 178 & 2666 & 806 & 15600 & 0.17 \\
\hline $1959 / 60$ & 479 & 154 & 424 & 176 & 171 & 88 & 1074 & 418 & 13800 & 0.08 \\
\hline $1960 / 61$ & 874 & 249 & 193 & 88 & 274 & 124 & 1341 & 461 & 15300 & 0.09 \\
\hline Total & 5648 & 1253 & 3843 & 1260 & 1563 & 598 & 11054 & 3111 & 89100 & 0.12 \\
\hline $\begin{array}{l}\text { Add1tional } \\
\text { raptures } \\
\text { in } 1901 / 62\end{array}$ & 79 & - & 34 & - & 17 & - & 130 & & & \\
\hline
\end{tabular}

During the first three years of observations inspection was made daily, with the exception of Sundays, of the bait, to see what had been eaten and new bait was sprinkled on all the sites. In the following three years bait was sprinkled every other day so that the day for capturing the mice was preceded by the day on which bait was sprinkled. It proved that bait laid in this way did not reduce the number of captures.

In accordance with the method adopted, traps were set in the study for two days in each week (usually Tuesdays and Wednesdays). A longer interval occured oniy in March 1958, and in January up to mid-February 1960, on account of the very heavy fall of snow, which reduced the efficiency of the traps to such an extent that the captures were not comparable (bait was sprinkled as usual during this time).

During the observation period 297 times, traps were set for two days. After multiplying by 4 (number of inspections) and 75 (number of traps set at one time) a total 
of 89100 chances of catching the rodents was obtained. This is a figure analogical to the frequently-used index of trap-days. This figure characterises the intensity of penetration of the area by the investigator.

The number of captures, number of individuals captured, number of chances of capture and percentage of occupation of the traps, divided according to each species and year of observation, are given in table 1 .

\section{TRAPPABILITY}

\section{Description of trappability}

A basic condition for the solution of the problem discussed in this study is the attainment of such intensive capture of the animals living in the study area as to be able within the shortest possible time to capture and mark every individual.

It was found that by means of the method used $75-95 \%$ of all the individuals living in the study area were caught within 6 days of trapping (Andrzejewski \& Wrocławek, 1962).

A description of frequency of captures by the mean number of captures of an individual within a defined unit of time involves the determination of the periods of stay of individuals in the study area. This is impossible without a certain preliminary method of capture. This is discussed in greater detail in Section VII. Without making this analysis, however, it is possible to describe frequency of capture by an analysis of the intervals of time between two consecutive captures of each individual.

If the first capture of the individual, which is necessary in order to reveal its presence in the study area, is excluded from calculations, then the mean section of time between captures is the reciprocal of the mean number of captures of an individual within a unit of time.

The mean number of captures in a unit of time $(\mathrm{m})$ is expressed by the ratio of number of captures of an individual $(\mathrm{m})$ minus the first capture, to the number of weeks $(t)$ which elapsed between the first and last capture:

$$
\overline{\mathrm{m}}=\frac{\mathrm{m}=1}{\mathrm{t}} \text {. }
$$

It is obvious that the reciprocal relation expresses the mean section of time between captures. Therefore the higher the values taken on by the mean section between captures, the more seldom the animals are caught; the lower the values, the more frequent the captures.

As explained in the description of methods used, the traps were set twice a week in the study area. The animals were removed from them twice during the day, about midnight and in the morning. Since, as our observations showed, the diameter of the home ranges of the species discussed in this study was greater than the distance between two rows of traps, each individual was liable to be caught 4 times in a week; twice 
on the first day of trapping in the row with odd numbers, and twice on the second day of trapping in the row with even numbers.

The method of trapping meant that we could expect the following sections of time separating two consecutive captures of the same individual: half a night, 24 hours, 24 hours + half a night, two 24-hour periods, one week, one week and half a night etc. In continuing these reasonirigs one week has been taken for purposes of simplification as the unit of time between two consecutive captures, and the sections of time separating two captures within one week have been treated jointly, marking them as less than one week.
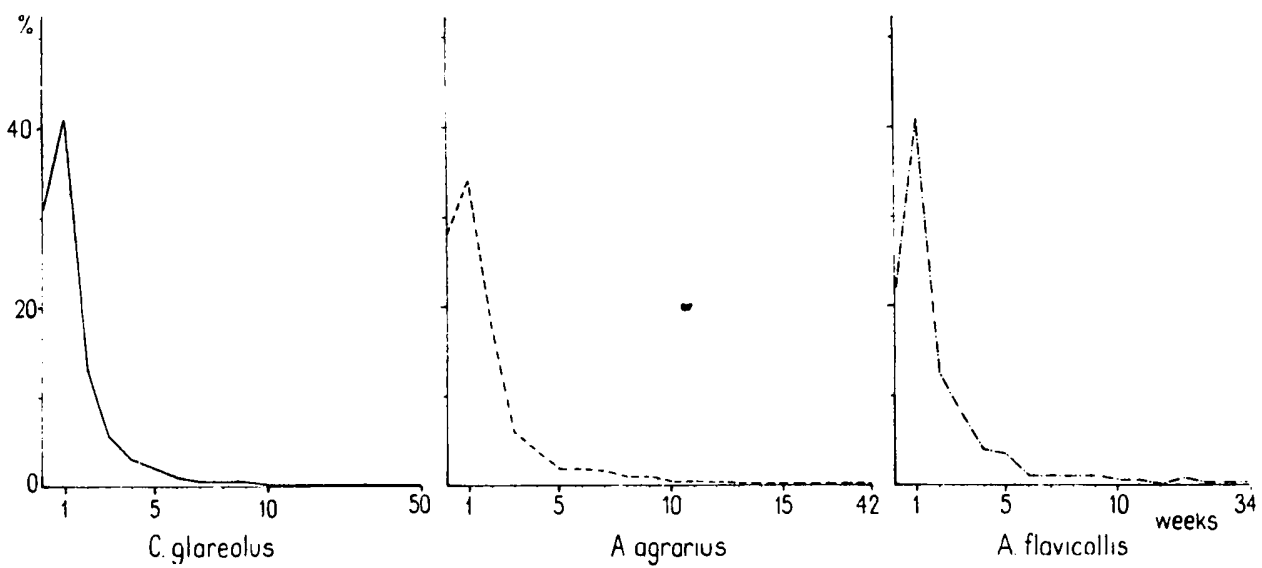

Fig. 1. Distributions of time intervals between captures (jointly for all the observation years). Axis $\mathbf{x}-\%$ formed by intervals of given length in relation to all intervals, axis $\mathbf{y}$ - length of interwals in weeks.

After defining, in accordance with the weekly scale described above, the intervals of time for each consecutive two captures, calculation was made of the frequency of occurrence of each value of these intervals (Fig. 1).

In turn calculation was made of the series of values illustrating the percentage formed jointly by the sections of time shorter than one week plus weekly sections, sections shorter than weekly ones plus weekly sections, plus two-weekly ones etc. (cumulated distribution of time sections between captures).

We can see that, generally speaking, for the whole study period in the case of C. glareolus $90 \%$ of all intervals between captures come within limits of up to 3 weeks, A. flavicollis 4 weeks and $A$. agrarius to 5 wetks (Table 2).

Comparison of the periods within which $90 \%$ of all captures for the whole material and for different years of observations are distributcd 
shows that with $C$. glareolus this period did not change during successive years. The value of the percentage attained in 1957/58 and in 1958/59 after 3 weeks does not differ significantly from the value of $90 \%$ attained jointly during the whole study period up to this week (Table 2).

In the case of $A$. agrarius greater fluctuations occur in different years. Statistically significant deviations are exhibited in 1955/56 and 1960/61, in which this species was captured less frequently than jointly in all the

Table 2.

Cumulated distributions of time sections between captures of:

\begin{tabular}{|c|c|c|c|c|c|c|c|c|c|c|}
\hline \multirow[b]{2}{*}{ Year } & \multicolumn{9}{|c|}{ Clethrionomjs glareolus } & \multirow[b]{2}{*}{$1955 / 56$} \\
\hline & $1955 / 56$ & $1956 / 57$ & $1957 / 58$ & $1958 / 59$ & $1959 / 60$ & $1960 / 61$ & 99 & 68 & Total & \\
\hline$\Sigma$ & 1368 & 617 & 319 & 435 & .330 & 624 & 1664 & 2029 & 3693 & 598 \\
\hline$<1$ & 31.36 & 33.87 & 29.47 & 31.26 & 38.78 & 24.51 & 31.11 & 31.11 & 31.11 & 25.41 \\
\hline 1 & 70.83 & 73.57 & 66.14 & 68.50 & 76.96 & 75.95 & 72.00 & 72.00 & 72.02 & 51.66 \\
\hline 2 & 84.06 & 87.02 & 80.56 & $81.37=$ & 86.96 & 88.61 & 85.50 & 84.50 & 84.96 & 66.37 \\
\hline 3 & 90.05 & 22.21 & 87.14 & 87.81 & 81.81 & 03.10 & $\underline{90.90}$ & 90.30 & $\underline{90.56}$ & 73.73 \\
\hline 4 & 93.19 & 94.32 & $\underline{92.15}$ & 89.88 & 95.14 & 96.30 & 93.88 & 93.40 & 93.59 & 80.08 \\
\hline 5 & 94.94 & 96.26 & $\overline{95.28}$ & 93.10 & 96.96 & 97.26 & 96.00 & 95.20 & 95.54 & 84.26 \\
\hline 6 & 96.40 & 96.91 & 97. 10 & $\overline{94.71}$ & 98.17 & 98.22 & 96.90 & 96.80 & 96.81 & 86.43 \\
\hline 7 & 96.91 & 97.88 & & 95.17 & 98.47 & 98.38 & 97.32 & 97.29 & 97.27 & 88.77 \\
\hline 8 & 97.79 & 98.53 & 97.79 & 95.40 & 98.77 & 98.54 & 97.74 & 97.98 & 97.84 & $\underline{90.61}$ \\
\hline 9 & 98.45 & 99.02 & 96.73 & 96.32 & & 98.88 & 98.34 & 98.52 & 98.43 & 91.28 \\
\hline 10 & 98.81 & 99.34 & & 96.78 & & 99.18 & 98.58 & 98.86 & 98.71 & 93.12 \\
\hline 11 & 98.96 & & 99.04 & 98.39 & 99.39 & & $99 . \dot{06}$ & 99.06 & 99.03 & 93.96 \\
\hline 12 & 99.03 & & 99.35 & 99.09 & & & 99.12 & 99.26 & 99.16 & 94.46 \\
\hline 1) & & & & & & 99.50 & 99.18 & 99.31 & 99.21 & 94.96 \\
\hline 14 & 99.18 & 99.50 & & & & & 99.24 & 99.41 & 99.29 & 95.29 \\
\hline 15 & 99.33 & 99.66 & & 99.32 & & & 99.30 & 99.56 & 99.40 & 95.79 \\
\hline$>15$ & 100.00 & 100.00 & 100.00 & 100.00 & 100.00 & 100.00 & 100.00 & 100.00 & 100.00 & 100.00 \\
\hline
\end{tabular}

years and in 1958/59, in which it was caught more frequently. I cannot put forward any suggestions as to the cause of these variations.

The small numbers of $A$. flavicollis occurring in the study area made it impossible to calculate the deviations shown by this index for each year.

The results obtained mean that $C$. glareolus is more often caught in traps than $A$. agrarius and $A$. flavicollis. The frequency of capture is therefore different in the case of different species even when the same method is used.

If the same indices for the two sexes are compared, we see very considerable coincidence between males and females in each species. This means that sex does not affect the frequency of visits made to the traps.

\section{Seasonal variations in trappability}

It is not possible to describe the seasonal variations in trappability on the basis of the index used above, since frequently the sections of time 
between captures are so long that they cover the whole season observed, or only partly come within the season observed, and partly overlap into the successive season.

As indicated at the beginning of this section, determination of the life span of an individual in the study area involves the use of the analysis made in section VII. Taking these data as a basis, calculation was made for each month of the mean numbers of captures per week of stay of the

a) Clethrionomys glareolus, b) Apodemus agrarius, c) Apodemus flavicollis.

\begin{tabular}{|c|c|c|c|c|c|c|c|c|c|c|}
\hline \multicolumn{7}{|c|}{ Apodemus agrartus } & - & \multicolumn{3}{|c|}{ Apodemus Plavicollis } \\
\hline $1956 / 57$ & $1957 / 58$ & $1958 / 59$ & $1959 / 60$ & $1960 / 61$ & $q q$ & $80^{\circ}$ & Total & $q q$ & $80^{\circ}$ & Total \\
\hline 415 & 129 & 1269 & 248 & 114 & 1331 & 1442 & 2773 & 458 & 534 & 992 \\
\hline 25.54 & 24.81 & 32.94 & 33.87 & 11.40 & 29.60 & 28.50 & 29.03 & 20.08 & 22.85 & 21.57 \\
\hline 55.90 & 52.72 & 72.02 & 73.79 & 46.49 & 63.40 & 63.40 & 63.43 & 60.47 & 64.80 & 62.80 \\
\hline 72.53 & 72.32 & 85.26 & 87.50 & 69.30 & 78.70 & 77.60 & 78.18 & 76.44 & 78.47 & 77.52 \\
\hline 78.34 & 80.62 & 89.59 & 93.14 & 78.07 & 84.20 & 83.60 & 83.91 & 84.30 & 86.52 & 85.48 \\
\hline 82.89 & 89.15 & 92.43 & 94.75 & 84.21 & 88.40 & 87.70 & 88.06 & 88.67 & 90.45 & 89.61 \\
\hline 85.78 & 91.47 & $\overline{93.69}$ & 95.56 & 87.72 & 90.30 & 90.30 & 90.29 & 92.60 & $\overline{93.63}$ & 93.14 \\
\hline 87.95 & 94.57 & 95.19 & 97.58 & 88.60 & $\overline{92.30}$ & 92.00 & 92.13 & 94.35 & 94.75 & 94.55 \\
\hline 91.56 & & 96.21 & 98.39 & 90.35 & 93.60 & 94.00 & 93.79 & 94.79 & 95.87 & 95.36 \\
\hline 93.00 & & 97.00 & & 91.23 & 94.80 & 94.83 & 94.80 & 95.23 & 96.81 & 96.07 \\
\hline 94.93 & 96.12 & 97.55 & 98.79 & 93.86 & 95.63 & 95.80 & 95.70 & 96.10 & 97.37 & 96.78 \\
\hline 35.41 & & 97.79 & & & 96.46 & $96.1=$ & 96.28 & 96.97 & & 97.18 \\
\hline 96.37 & & 98,18 & & 94.74 & 96.76 & 96.94 & 96.82 & 97.41 & 97.56 & 97.48 \\
\hline \multirow[t]{3}{*}{97.09} & & 98.57 & 99.19 & 96.49 & 97.06 & 97.60 & 97.32 & 97.85 & & 97.68 \\
\hline & 96.89 & 98.81 & & 97.37 & 97.51 & 97.74 & 97.61 & 98.29 & & 98.04 \\
\hline & & 98.97 & & & 97.58 & 97.95 & 97.75 & & & 98.04 \\
\hline 97.33 & & 99.13 & & 98.25 & 97.65 & 98.37 & 98.00 & 98.73 & 98.12 & 98.14 \\
\hline 100.00 & 100.00 & 10c.co & 100.00 & 100.00 & 100.00 & 100.00 & 100.00 & 100.00 & 100.00 & 100.00 \\
\hline
\end{tabular}

mice in the study area, excluding the week of capture for the first time of the given animal (for this week the mean must have a value of $>1$, since each animal in the first week, during which traps are set for it, must be caught at least once in order to be registered at all).

The index obtained exhibits considerable variation in time. If the meari value of the index is calculated for each month, summing up the number of captures of rodents and number of weeks of stay of the animals in the study area from all the observation years, then the index exhibits certain regular variations (Fig. 2).

In the case of $C$. glareolus we have a decrease in trappability in the winter (particularly in January, February) and a balanced higher trappability in the summer (April-October). In the case of $A$. agrarius with a total lower trappability (according to the analysis previously considered of the mean section of time between captures), there is also a distinc: winter decrease in trappability (the smallest values of the index are those 
for January, February); during the summer period the index of trappability exhibits mean values, to rise in September and October to a higher index of trappability. With $A$. flavicollis the general picture of trappability is fairly similar to that of $C$. glareolus.

Trappability may depend on: 1 . the method of capture used (effectiveness of capture of animals by the traps used), and 2. the actual tendancy of the animals to enter the traps.

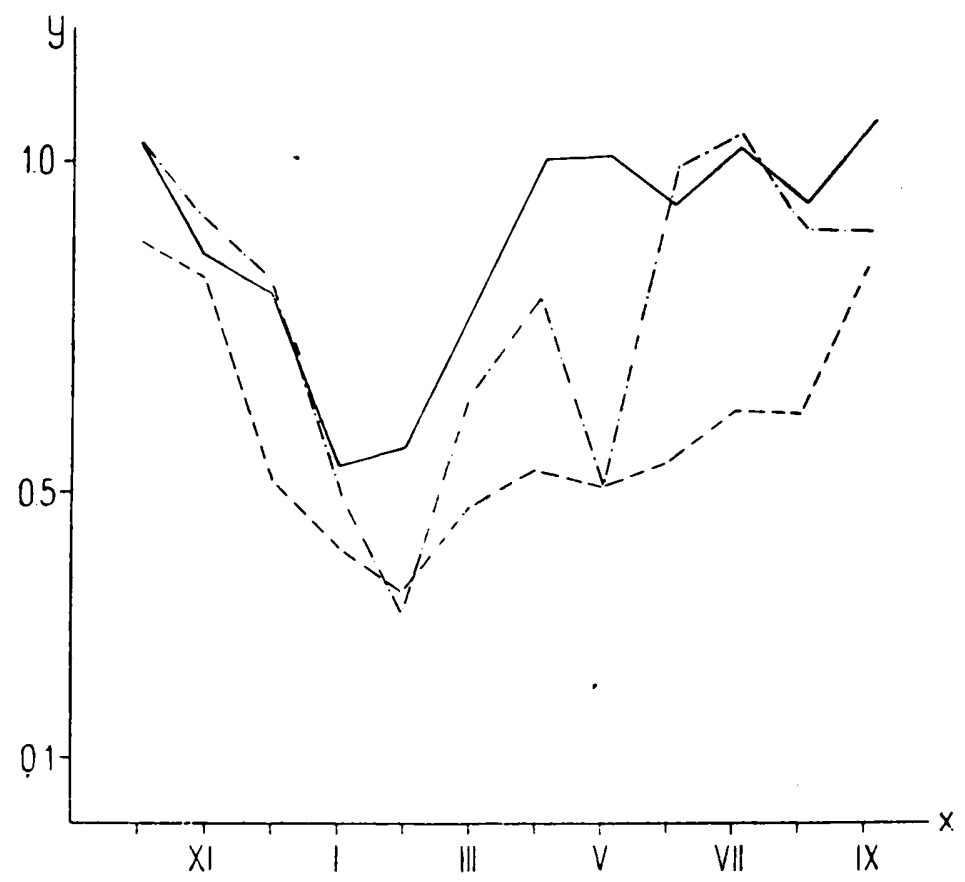

Fig. 2. Variations in trappability during the yearly cycle. Axis $x$-months, axis $y$ - mean number of captures per week of residence of the individual in the study area, - C. glareolus, - - - A. agrarius - - - - A. flavicollis.

The winter reduction in trappability, which occurs in all the species examined, may be the result either of the real decrease in activity of visits by the animals to the baited sites with the traps, or may be the result of the reduction of the efficiency of the traps caused by weather conditions (freezing up of the movable parts). The difficulties which the animals have in searching for food from the natural food supply should rather cause more intensive visiting of the sites - the decrease in trappability would therefore seem to be caused by the method of trapping. This may be further indicated by the parallel character of the decrease in all three species. 
The autumn increase in the frequency of captures in the case of A. agra. rius is rather due to the actual increase in trappability, since there is no reason for supposing that the traps acted better under autumn weather conditions (in relation to the summer functioning should rather be worse) and selectively in relation to one species only.

3. Trappability of an individual during the period of its stay in the study area

A condition for the success of the method used in this work is that with the repeated captures, the individual should not learn either to avoid

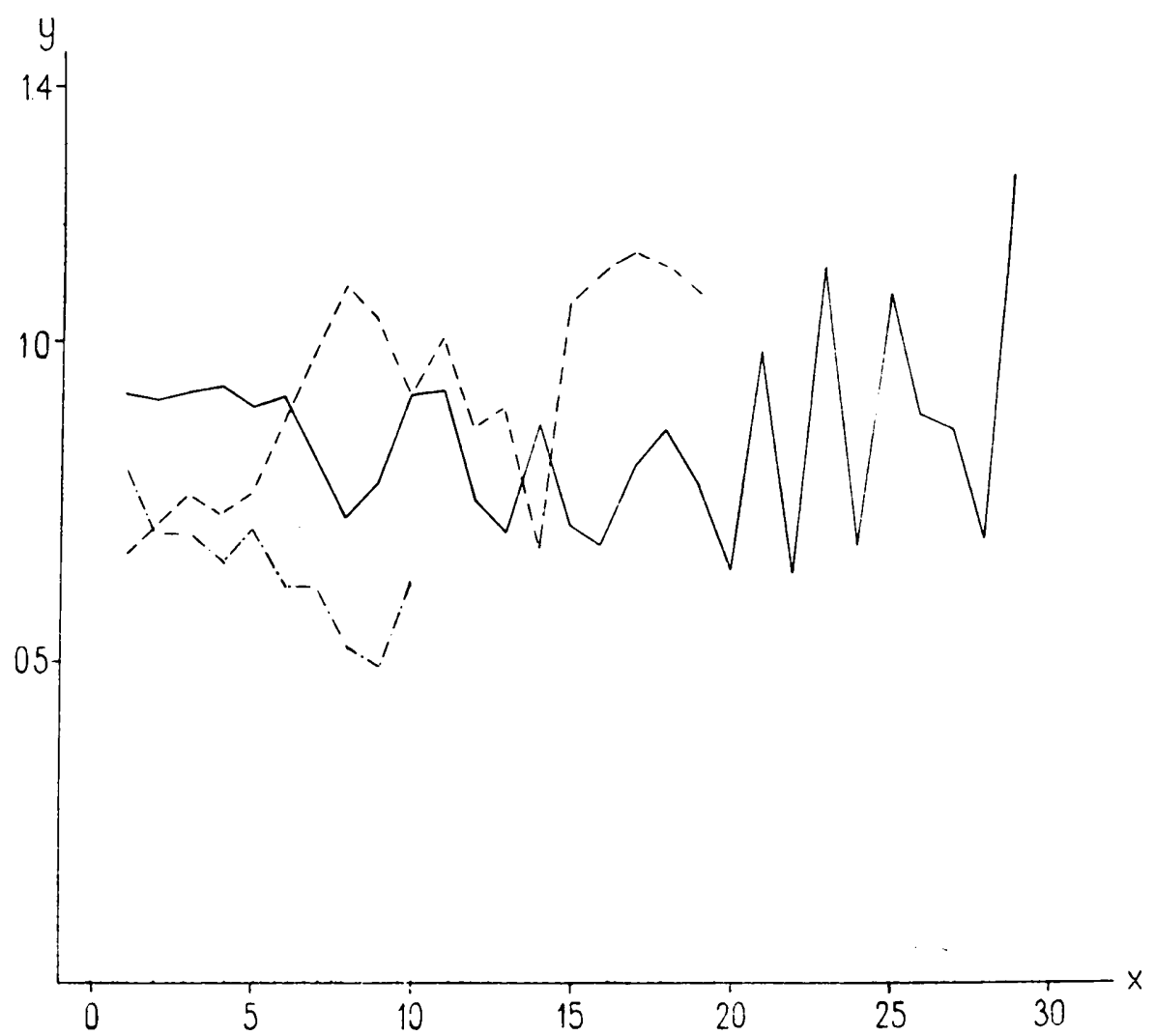

Fig. 3. Variations in trappability during the time spent by the individual in the study area. Axis $x$ - weeks of residence of the individual in the study area, axis $\mathbf{y}$ - mean number of captures per week of residence. Symbols for species as in Fig. 2.

being caught in the trap, or to visit it more often. If either of these two eventualities did occur, it would cause variations in trappability with the 
lapse of time from the first capture of the given rodent. Calculation was made for each species of the mean number of captures in successive wetks of stay of the individual in the study area. A series of such mean values illustrates the variations in frequency of capture during the time the individual is living in the study area (Fig. 3).

The mean values obtained for all the species fluctuate in successive weeks, from the second week of stay of the individual in the study area fortuitously in plus and in minus round the straight line parallel to axis $\mathrm{X}$. This makes it possible to conclude that despite intensive trapping the individuals do not change their trappability with the lapse of time from the moment of settling in the study area (Fig. 3). This shows that under our conditions we did not observe any directional process of avoiding or becoming accustomed to being caught during the time the irdividuals spent in the study area.

Different authors in other investigations found that the frequency of captures may change directionally during consecutive captures (e.g. Y o u ng, S tr e cke r \& Emle n, 1950). It must therefore be concluded that the directional charakter of the course taken by variations in frequency of capture may vary in different conditions.

\section{Total capture of new individuals}

If the frequency of captures of mice from the time of the first to the last capture, as I showed above, does not undergo any changes, then it would seem probable that the process of catching new individuals from the time that they settle in the area (or from the traps are set in the first phase of investigations in the given area) to their first capture, should take place according to the frequency of capture defined by the distribution of trappability (Fig. 1). Thus $90 \%$ of the freshly settled C. glareolus will have been caught, for instance, after three weeks, but not until after 5 weeks in the case of $A$. agrarius.

In reality, however, this period may be slightly shorter, since among the long intervals of time between consecutive captures intervals may occur which are caused by a certain mouse leaving the study area and returning to it after a certain time. The exclusion of such intervals would reduce the total number of intervals and thus raise the percentage of short time sections.

It should therefore be expected that the time required for catching and marking all the individuals in a given area for each species of rodents (that is, the species considered in this study), will be different and characterised by the frequency of their captures (in our case, e.g. distributions of intervals of time between captures). 


\section{LENGTH OF STAY OF INDIVIDUALS IN THE STUDY ARFA}

\section{General remarks}

It must be expected that two groups of individuals - settled and migrating individuals, can be distinguished in the study area in the populations of each species of rodents.

If repeat captures of a certain individual in the area occur sufficiently frequently, then we can take it that between these captures this individuals lives in that area or at least near its limit - and is therefore settied.

If-the period between two captures of a given individual is a long one it may have happened, in accordance with what we said previously, that the given individual emigrated for some time from the area, after which time it came back into the area.

The statistical picture of these two possibilities is the distribution of sections of time between two consecutive captures (discussed in Section $\mathrm{V}-$ Fig. 1).

Taking into consideration the previous reasonings as to the possibilities of capturing all the individuals of different species and also simplifying the case, I took it that among all the sections of time between captures, only $7 \%$ of the longest can indicate that during this time the given individual emigrated from the study area and then returned to it again. The remaining $93 \%$ were captures within the limits of the constant movements of the animals through the study area.

The different frequency of captures in the case of each species causes the accepted $7 \%$ to include in different species a different range of length of time sections between captures. Thus the permissible interval for assuming that the individual emigrated from the study area and returned to it is in the case of C. glareolus, over 4 weeks, for A. agrarius over 7 weeks and for $A$. flavicollis over 5 weeks, since time sections of these lengths between two captures form the accepted $7 \%$ for these species (Table 2).

It would seem that the accepted $7 \%$ sufficiently reduces the increase in the time of stay and abundance of animals caused by intervals in the stay in the study area of different individuals.

On the other hand the acceptance of different values of this percentage does not.basically alter the picture of variations in numbers ( $\mathrm{P}$ e $\mathrm{tr} \mathrm{u}$ sew i c $z$, in litt.).

By now applying these assumptions we can establish for each individual its probable time of stay in the study area. This time will be equal to the period which has elapsed from the first to the last capture of the given mouse, unless a time section longer than that fixed above occurred between each capture. Where such an interval occured in captures I have 
assumed that the given mouse left the study area and returned to it again.

Sections established in the way of the time spent by the individuals in the study area are shorter than the real times of stay of different individuals by the time between settlement in the area and the rirst capture, and by the time which elapsed from the last capture to the true disappearance from the study area. As already stated, the length of the section before the first capture and similarly the length of the section after the final capture, depends on and is defined by the frequency (distribution) of captures of the given species.

After determining the time of stay in the study area for each individual we can begin to analyse the material from the aspect of the composition of the population in the study area.

\section{Distribution of length of stay}

The distributions of length of stay in the study area of the given group of individuals were compared, and graphically represented by curves of length of stay (Andrzejewski \& Wierzbowska, 1960; 1961: Andrzejewski \& Wrocławek, 1961).

Data for defining these distributions were obtained from comparisons made by the "calendar of captures" method (Petrusewicz \& A ndrzejewski, 1962), cumulated according to the enclosed formula (Table 3).

In this plan the figures distributed in diagonal lines make it possible to trace the number of rodents which lived for a defined number of weeks from the group of rodents caught for the first time in a certain period (a week - A). The diagonal row of figures is therefore the cumulated distribution of length of stay of the group of animals caught for the first time in a defined week. In order to obtain the distribution of length of stay of the group of animals caught for the first time during a longer section of time, it is only necessary to sum up the figures in the lines contained between the two diagonal lines forming the limits of this section of time. At the same time the vertical column indicates to which week from the start of observations (or from the calendar time) the given group of mice survived.

Andrzejewski \& Wierzbowska $(1960,1961)$, using the present materials from $1955 / 56-1957 / 58$, showed that:

1. the group of individuals caught for the first time has a higher percentage of disappearance during the first week after capture than in the following weeks of stay in the study area.

2. if we exclude from the curve (distribution) of stay the week in which the individuals were caught for the first time $\left(t_{0}\right)$, then the remaining 
section of the curve (distribution) has the form of an exponential function. This means that the rate of disappearance of the group of animals staying in the study area for longer than one week (caught several times), and therefore resident in the area, is constant.

If the rate of disappearance of the settled animals is constant then it may be assumed, that it also is constant and similar in the first week after the first capture (Andrzejewski \& Wi er zbowska, 1960; 1961).

An analysis of trappability makes it possible to assume that only a small percentage of the rodents are caught as early as the week of actual settlement in the given area, and that the majority of them have chances of being caught after two or three weeks of trapping. This means therefore

Table 3.

Cumulated data from "calendar of captures" - sector of comparison (Description in text).

\begin{tabular}{|c|c|c|c|c|c|c|c|c|c|c|c|c|c|c|c|c|c|c|c|c|c|c|c|c|c|c|}
\hline \multicolumn{4}{|c|}{ IX. 1957} & \multicolumn{5}{|c|}{$x$} & \multicolumn{4}{|c|}{$X I$} & \multicolumn{4}{|c|}{$x I 1$} & \multicolumn{4}{|c|}{ I. 1958} & \multicolumn{4}{|c|}{ II } & \multicolumn{2}{|c|}{ III } \\
\hline A & 8 & 10 & 10 & 15 & 19 & 7 & 9 & , & 4 & 6 & 6 & 3 & 2 & 4 & 3 & 5 & 11 & 9 & 3 & 6 & 11 & 0 & & & 2 & \\
\hline 1 & & & & & 13 & & & & & & & & & & & & & & & & & & & & & \\
\hline 3 & & & & & & & & & & & & & & & & 2 & & & 3 & & & & & & & \\
\hline 4 & & & & & & & & & & & & & & & & & & & & 3 & & & & & & \\
\hline s & & & & & & & & & & & & & & & & & & & & & & & & & & \\
\hline 6 & & & & & & & & & & & & & & & & & & & & & .2 & 3 & & & & \\
\hline 7 & & & & & & & & & & & & & & & & & & & & & & & & & & \\
\hline 8 & & & & & & & & & & & & 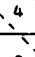 & & & & & & & & & & & & & & \\
\hline & & & & & & & & & & & & & & & & & & & & & & & & & & \\
\hline & & & & & & & & & & & & & 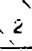 & & & & & & & & & & & & & \\
\hline 12 & & & & & & & & & & & & & & & & & & & & & & & & & & \\
\hline 3 & & & & & & & & & & & & & & & & & & & $\therefore$ & & & & & & & \\
\hline & & & & & & & & & & & & & & & & & & & & & & & & & & \\
\hline & & & & & & & & & & & & & & & & & & & & & & & & & & \\
\hline 6 & & & & & & & & & & & & & & & & & & & & & & & & & & \\
\hline & & & & & & & & & & & & & 3 & & & $\therefore$ & $\rightarrow$ & & 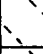 & & \. & & 1 & & & \\
\hline & & & & & & & & & & & & & & & & & & & & & & & & & & \\
\hline & & & & & & & & & & & & & & & & & & & & & 下, & 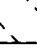 & 1 & & 1 & \\
\hline$x$ & 11 & 12 & 17 & 27 & 33 & 32 & 30 & 28 & 26 & 24 & 24 & 18 & 18 & 15 & 12 & 12 & 17 & 17 & 19 & 12 & 10 & 9 & 7 & 4 & 5 & 5 \\
\hline
\end{tabular}


that the settled individuals caught for the first time usually live in the study area for a certain period before they are caught for the first time Therefore the greater part of these individuals have time to get accustomed to a habitat situation (getting to know the area, building nest: etc.) and population situation (defining of contacts with their neighbours

Table 4

Results of analysis of distributions of lengt!

\begin{tabular}{|c|c|c|c|c|c|c|c|c|}
\hline Spec1es & A. flav1coll1s & & & & Elareolu & & & \\
\hline tear & $1955 / 56$ & $.1955 / 56$ & $1956 / 57$ & $1957 / 58$ & $1958 / 59$ & $1959 / 60$ & $1960 / 61$ & $1955 / 56$ \\
\hline$P_{1}^{*}$ & 0.3027 & c. 1655 & 0.3225 & 0.3217 & 0.2898 & 0.2793 & 0.2331 & 0.3959 \\
\hline $\bar{t}$ & 5.25 & 7.82 & 4.48 & 4.50 & 3.46 & 3.58 & 4.29 & 5.25 \\
\hline$S_{(f)}$ & 0.633 & 0.556 & 0.389 & 0.475 & 0.302 & 0.358 & 0.420 & 0.389 \\
\hline$N_{0}$ & 117 & 261 & 203 & 132 & 248 & 154 & 249 & 230 \\
\hline $\mathrm{N}_{0}^{:}$ & 68.9 & 197.76 & 132.48 & 39.9 & 130.84 & 22.53 & 166.63 & 122.33 \\
\hline 的 & 48.1 & 63.24 & 70.52 & 48.1 & 117.16 & 61.47 & 82.37 & 107.67 \\
\hline $\begin{array}{c}\text { No. of migrating } \\
\text { in } x\end{array}$ & 0.41 & 0.24 & 0.35 & 0.35 & 0.47 & 0.60 & 0.67 & 0.47 \\
\hline $\begin{array}{c}\text { Nic. of settled } \\
\text { in } x\end{array}$ & 0.59 & 0.76 & 0.65 & 0.65 & 0.53 & 0.40 & 0.33 & 0.53 \\
\hline$N_{1}$ & 57 & 174 & 106 & 72 & 98 & 70 & 132 & 97 \\
\hline
\end{tabular}

$\mathrm{P}_{1}$ - index of disappearance ( $\%$ disappearing in each week),

$t$ - average length of residence,

$\mathrm{S}_{\mathrm{t}}$ - error in average,

$\mathrm{N}_{\mathrm{o}}$ - number of rodents captured for the first time,

$\mathrm{N}_{\mathrm{o}}^{\prime \prime}$ - number of migrating individuals,

$\widetilde{N}_{0}$ - number of freshly settled individuals,

$\mathrm{N}_{1}$ - number of animals settled for at least one week.

similar to that of the individuals caught in the weeks following the firs: capture.

Acceptance of the assumption that settled individuals disappear durin; the first week following the first capture in the same way as in late: weeks makes it possible to extrapolate the function of disappearance $\alpha$ the animals to the first week after the first capture $\left(t_{0}\right)$ and estimate th? number of settled individuals in the group of individuals caught for th: first time (A.ndrzejewski \& W i e r zbowska, 1960; 1961).

In turn definition of the parameters of the exponential function make; it easy to calculate the mean length of stay of settled individuals in th: study area in different years (A ndrze je wski \& Wi e r zbows k , $1960 ; 1961)$.

Using the method described above, the function of periods of th: rodents' stay in the study area was defined for each species and in eaci year, with the exception of $A$. flavicollis, where the size of the matericl 
only permitted of calculations for $1955 / 56$ and for the whole material (Table 4) ${ }^{3}$ ). The distribution of length of stay of the animals is exponential for all the three species living in the study area in each year of observations, and for the males and females of each species for the whole observation period, with the exception of A. agrarius in 1958/5?.

of residence of rodents in the study area.

\begin{tabular}{|c|c|c|c|c|c|c|c|c|c|c|}
\hline \multicolumn{5}{|c|}{ A. agrarius } & \multicolumn{2}{|c|}{ A.flavicoll1s } & \multicolumn{2}{|c|}{ C.glareolus } & \multicolumn{2}{|c|}{ A. agrarius } \\
\hline $1956 / 57$ & $1957 / 58$ & $1958 / 59$ & $1959 / 60$ & $1960 / 61$ & $495 \frac{99}{5-61}$ & $\begin{array}{c}\text { ठक } \\
1955-61\end{array}$ & $\begin{array}{c}99+9 \\
1955-61\end{array}$ & $\begin{array}{c}\text { है } \\
1955-61\end{array}$ & $\begin{array}{c}90 \\
1955-61\end{array}$ & $\begin{array}{c}\text { ठర } \\
1955-61\end{array}$ \\
\hline 0.5008 & 0.4211 & 0.1466 & 0.2494 & 0.2493 & 0.2114 & 0.2386 & 0.1955 & 0.1926 & 0.2076 & 0.1984 \\
\hline 4.30 & 3.25 & & 4.01 & 4.01 & 4.74 & 4.18 & 5.128 & 5.181 & 4.81 & 5.05 \\
\hline 0.245 & 0.614 & & 0.614 & 0.483 & 0.4836 & 0.3947 & 0.4054 & 0.3027 & 0.3434 & 0.3227 \\
\hline 326 & 63 & 380 & 176 & 88 & 270 & 328 & 555 & 698 & 556 & 704 \\
\hline 176.71 & 36.6 & & 70.55 & 51.31 & 146.95 & 181.42 & 359.73 & 431.35 & 296.72 & 364.47 \\
\hline 149.28 & 26.4 & & 105.45 & 36.69 & 123.05 & 146.58 & 195.27 & 266.65 & 259.28 & 339.53 \\
\hline 0.65 & 0.42 & & 0.40 & 0.58 & 0.54 & 0.55 & 0.65 & 0.62 & 0.53 & 0.52 \\
\hline 0.35 & 0.58 & & 0.60 & 0.42 & 0.46 & 0.45 & 0.35 & 0.38 & 0.47 & 0.48 \\
\hline 130 & 28 & 190 & 55 & 40 & 119 & 143 & 296 & 356 & 241 & 289 \\
\hline
\end{tabular}

The distribution of the periods of stay of A. agrarius in 1958/59 has certain significant deviations from the exponential distribution calculated theoretically. This year is characterised by an exceptionally great abundance of this species, combined with a high mean length of stay of the animals in the study area (high degree of residency). It is possible that this last phenomenon caused difference in the rate of disappearance of the animals and in effect the distribution of disappearance does not fulfil the exponential function (Andrzejewski \& Wrocławek, 1961).

This fact prevented calculation directly from the exponential distribution of the mean length of stay of $A$. agrarius. This latter value was therefore estimated by calculating the sum of length of stay of each settled individual, assuming the first and last capture to define their length of stay, and dividing the sum thus obtained by the number of rodents.

The mean length of stay in all three species does not differ in principle, although there are fairly considerable deviations in the different years of observation. Neither does the mean time of stay of females and males differ (Table 4).

3) The estimate for $1955 / 56-1957 / 58$ was made in the study by Andrze je wsky \& Wierzbowska $(1960 ; 1961)$, for $1958 / 59$ in the study by Andrzejewski \& Wroc lawek (1961) and for the years mentioned above the material contained in the table were taken from these studies. 


\section{VARIATIONS IN NUMBERS}

\section{Introductory remarks}

Permanent and intensive trapping of rodents for 6 years continously makes it possible to assume that all the rodents caught for the first time in the study area are individuals new to this area, entering from the surrounding areas, or young individuals born in the study area and beginning active life in it. This also applies to rodents caught in the first captures entering into the scope of the materials presented in the present study (from October 1st 1955), since, as already stated, preliminary observations in the study area were carried out for 30 weeks before October 1st 1955 and the initial number of settled mice established.

As stated in the previous section, the group of rodents caught for the first time consists of the following individuals:

1. rodents about which we known that they are settled, as they continue to be caught in the following weeks,

2. ephemeral mice (this term was accapted after Petruse wicz \& A ndrze jew s k i, 1962) which are caught in the study area only in the week in which they were caught for the first time.

This latter group was divided into two categories on the basis of extrapolation of the distribution of periods of stay of the mice in the study area: a. migrating mice, not settling in the study area; b. pseudo-migrating mice, that is, also caught only in the week of their first capture, but originating from settled mice; they disappear from the study area either on account of re-transition into a migrating condition, or as a result of mortality in the week of their first capture (Petrusewicz \& Andrze jewski, 1962).

While each individual captured may be allocated to either the first or second group, groups $a$ and $b$ can only be distinguished statistically, estimating their participation in the second group (if we find that the distribution of periods of stay of the group of animals is exponential).

A condition essential to making such an estimate is that the number of animals entering in the section of time investigated is sufficiently large for a statistical estimation. This involves either the marking out of very large study areas, or to an estimate of the participation of settled. migrating and pseudo-migrating animals for lorig periods of time.

An estimate of this kind was made for $C$. glareolus and $A$. agrarius in each observation year, but in the case of A. flavicollis, on account of the insufficient number of individuals, it was made only for 1955/56 and also for all the species jointly from all the observation years, divided into males and females (Table 4). 
These calculations show that the participation of migrating individuals fluctuates within limits of $24-67 \%$, the range of fluctuations in the case of $C$. glareolus being slightly greater that with $A$. agrarius.

The percentage of pseudomigrating mice (comparison of $N_{0}$ and $N_{1}$ also exhibits fairly considerable variations, dictated chiefly by the coefficient of disappearance $\left(\mathrm{P}_{1}^{+}\right)$of settled mice (by their rate of disappearance).

The variability of the percentage of migrating mice and the coefficient of rate of disappearance cause differences in each year in the number of ephemeral mice.

The conclusion as to the variations in numbers of each species which can be drawn from data on the number of settled mice in each year are very poor in relation to the amount of work required to obtain them.

In order to trace variations in numbers in shorter sections of time, use was made only of those of the groups of mice distinguished, to which we can allocate individual animals on the basis of the picture of their captures. These will be:

1. individuals entering the area (new individuals) which are caught for the first time in the given week of inspection, and among them: a. ephemeral individuals, caught only in the first week following their first capture; $b$. individuals settling in and continuing to be caught in the weeks following the first capture;

2. settled individuals, caught again in the second and later weeks after the first capture;

3. disappearing individuals which were caught for the last time in the preceding week.

In summing up the number of individuals in the above groups in consecutive weeks of observations for the whole study area, it is possible to obtain the following table:

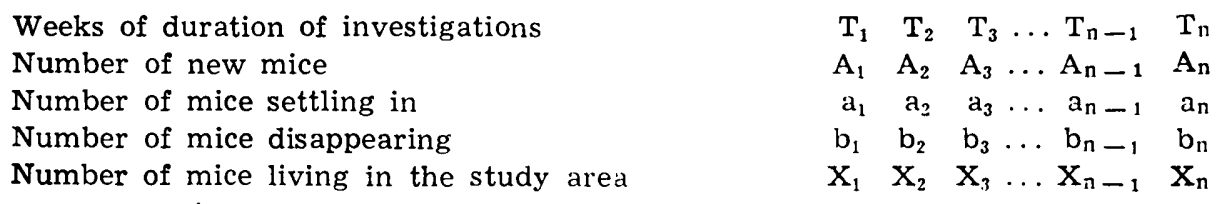

This comparison balances as follows:

$$
x_{n}=x_{n-1}+a_{n}-b_{n}
$$

Therefore the value $X_{1}$ to $X_{n}$ give us a picture of the variation in numbers of the given species of rodent during the period from $T_{1}$ to $T_{1}$.

The number of ephemeral mice $\left(B_{n}\right)$ in each of the weeks is:

$$
B_{n}=A_{n}-a_{n}
$$

The group of ephemeral mice does not enter into the number of mice $\left(X_{n}\right)$ calculated in this way. The "pseudomigrating" individuals do not enter 
into the estimation of the number of settled rodents, since as we already know (see Section V) they are also settled individuals, which however quickly disappear after the first capture. The number of settled mice is therefore reduced by the percentage formed by these individuals in relat-ion to the number of settled mice. The total value of this percentage for each year of observation can be estimated from determining the number cf pseudomigrating individuals, established on the basis of distributions of length of stay (Table 4).

The acceptance of such simplification in the determination of variations in numbers makes it possible to deal with the number of settled mice in very short units of time (equal to one sample).

In order to calculate the number of settled mice, use was made of comparisons of data obtained by the "calendar of captures" method, cumulating the data obtained in the form of a diagonal list (Table 3). The: vertical sums of figures in this comparison, excluding the first column, give the number of settled mice in weekly intervals. This comparison also gives the number of incoming mice (new) and also the number of mice settling in. The number of disappearing mice can be calculated according to the balance given above.

\section{Variations in numbers during the yearly cycle}

Variations in the numbers of each species during the study period in certain sections of time had certain features in common, and others differed considerably. Commonness of variations is probably the result of the similarity in the biology of these species and hence their similar reaction to the habitat and phenological variations taking place in the study area. On the other hand differences in the course taken by variations in numbers of these species may indicate periodic differences in their ecological situation.

In order to demonstrate certain regularities in the variations in numbers of the rodents in the yearly cycle, calculation was made from all the observations years of the mean numbers of individuals for each species in consecutive months of the year.

The data obtained in this way described the regularities on the basis of a mean value of 6 repeats ( 6 years observations). This is a fairly short time for this type of generalisation, since different factors such as phenological variations or variations the dynamics of the abundance of each species may cause wide deviations from this mean value (e.g. mass appearance of $A$. agrarius in 1959 , A ndrzejews k i \& W r ocławek, 1961). 
In comparing curves of variations in numbers over the yearly cycle we can observe a fairly high degree of coincidence in the course they take ini all three species. C. glareolus exhibits the least amplitude of variations, with the highest level of abundance. A. flavicollis has a small amplitude with the lowest level of abundance. A. agrarius exhibits the greatest differences in the levels of the number of individuals between spring and autumn (Fig. 4).

A summary of the variations in numbers in all three species faithfully reflects the synchronisation of these variations in the different species.

Taking the above variations in the number of rodents as a basis, we can distinguish during the yearly cycle two periods of peak numbers, and certain indications of a third: 1. the maximum autumn peak occurring in October-November, strongly expressed in all three species; 2. a spring peak, occurring in February-March. A certain inhibition of the summer tendency to increase is often observed in August, sometimes even becoming a slight decrease - this can be treated as defining the third summer period of peak numbers.

If we desire to present the dynamics discussed in the form of the decreases or increases which took place in a given month in comparison with the foregoing month, then 6 periods can be distinguished in the yearly cycle of variations in numbers in the study area (Fig. 6).

The first period (September, October

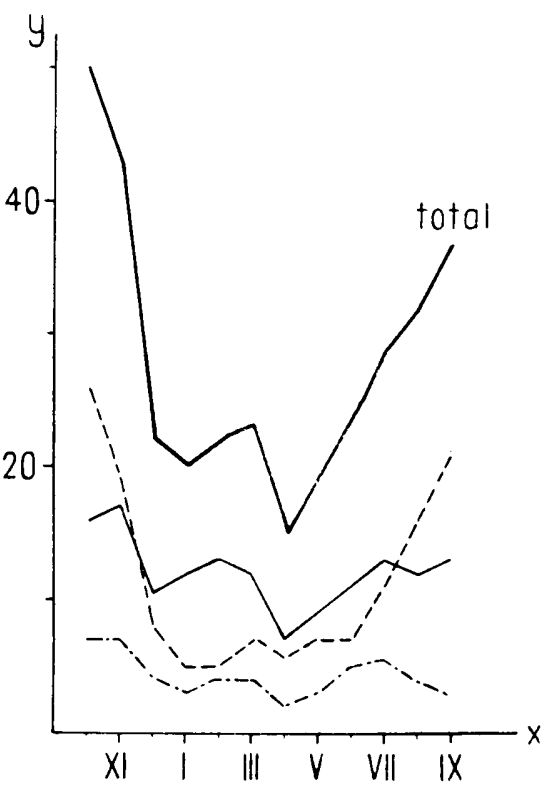

Fig. 4. Variations in the numbers of the rodents over the yearly cycle. Axis $\mathrm{x}$ - months, axis $\mathrm{y}$ - mean numbers of individuals. Symbols for species as in Fig. 2. and partly November) is a period of rapid increase and maximum abundance of the rodents.

The second period (December, January and often February as well) is a period of winter reduction in numbers; as a result the numbers of the animals reach a low level at the end of the winter.

The third period (February, and in particular March) is the pre-spring increase in abundance.

The fourth period (April), a further winter reduction of the animals depression in abundance, deepens still further in relation to the winte? minimum. 
The fifth period (May-July) - spring-summer increase in numbers.

The sixth period (August) - inhibition of the increase in numbers or even a certain slight tendency to decrease (Figs. 4, 5, 6).

It would seem that three factors play a decisive role in the formation of variations in numbers over the yearly cycle in the study area: during the summer period the increase in abundance takes place after the mating season, and it is difficult to state the causes for the inhibition of the process in August; during the winter and early spring period in principle

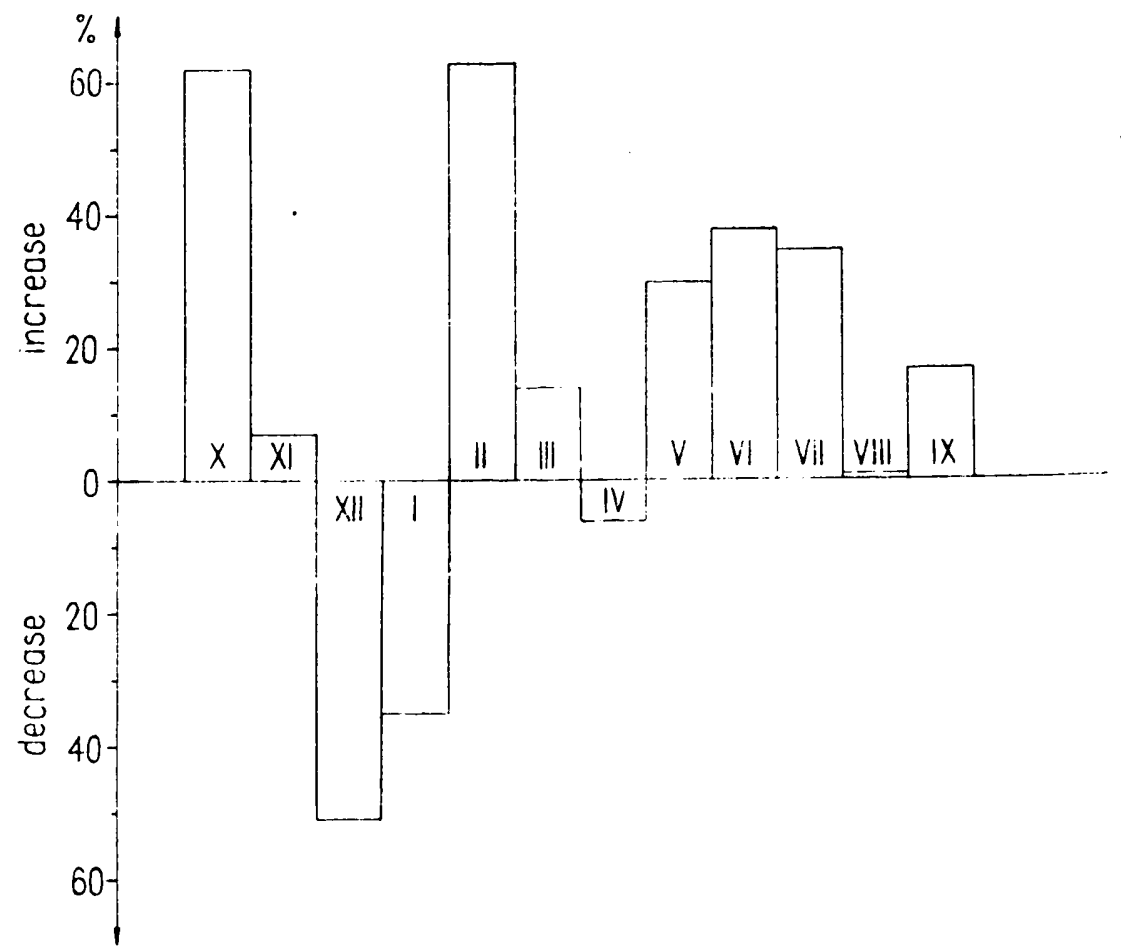

Fig. 5. Rate of increase and decrease in the number of rodents in each month of the year.

a reduction of the rodents by mortality takes place (reproduction, if it occurs during this period, does not play a significant part in variations in abundance); the process of reduction is interrupted during the pre-spring period by an increase in numbers, caused, it seems, by the immigration of rodents into the study area, connected with the spring thaw.

As indicated in the description of the area in which the investigations were made, fluctuations in the level of the ground water in the Kampinos: Forest are characterised by about $1.5 \mathrm{~m}$ amplitude. The spring thaw as a rule produces a violent and rapid rise in the level of ground water, 


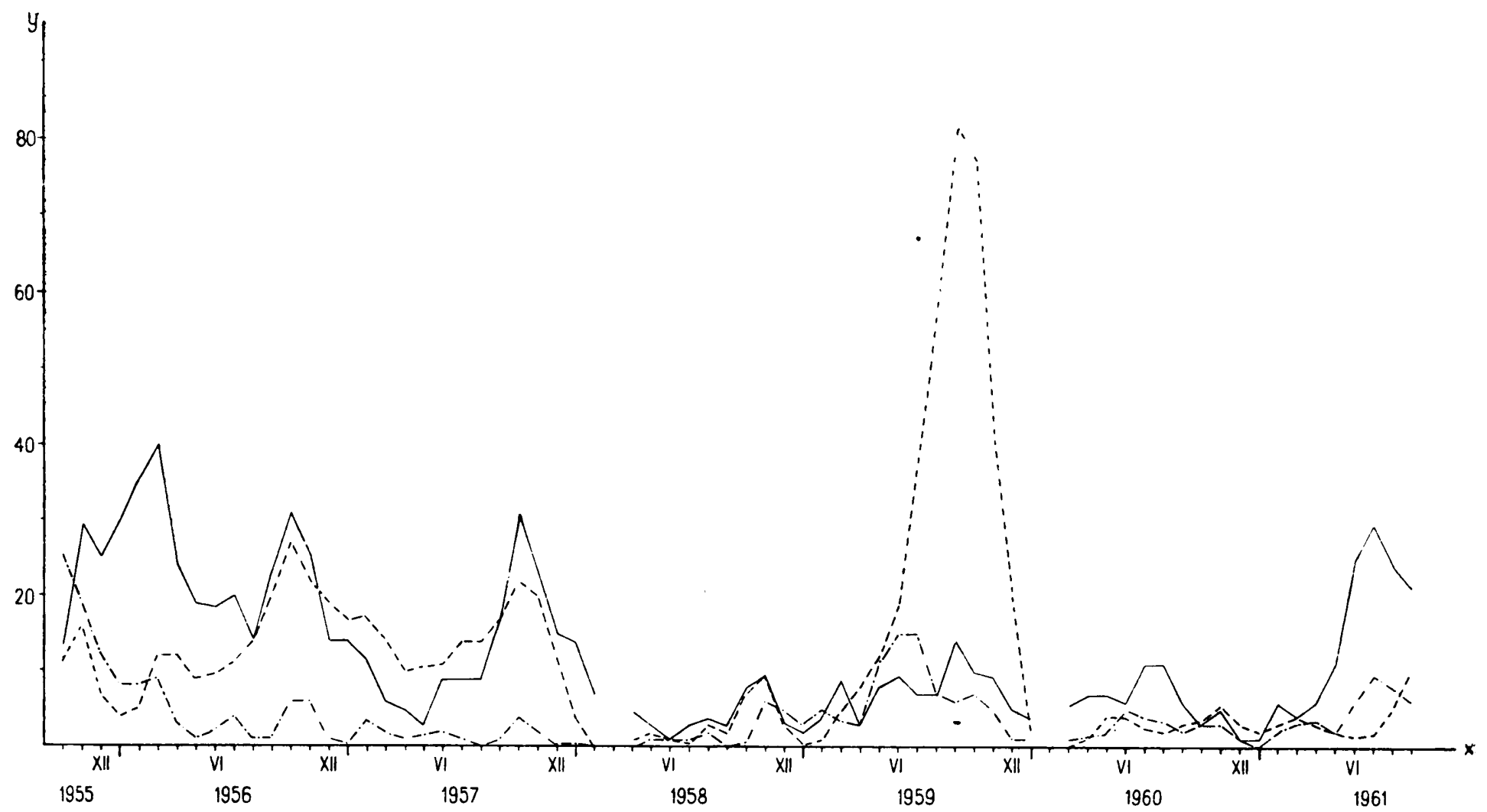

Fig. 6. Population dynamics of the rodents during the years 1956-1961. Axis y monthly averages of the number of rodents. Symbols for species as in Fig 2 . 
combined with the flooding of certain of the lower parts of the forest. The study area was partly above water level during the spring flooding. The spring period of peak numbers usually occurred immediately after the thaw, which as a rule takes place at the end of February or in March.

\section{Variations in numbers of particular species}

\section{A) C. glareolus}

During the study period this species exhibited the highest mean abundance (the more so if the short period of mass appearance of A. agrarius is not taken into consideration (Table 5).

The course taken by variations in the numbers of C. glareolus from 1955-196: was as follows:

In the autumn of $1955 \mathrm{C}$. glareolus attains a relatively high level of abundance. After a slight winter reduction and considerable increase in numbers during the spring thaw period the high level is maintained through the summer and autumn of 1956 . The winter reduction of $1956 / 57$ considerably lessened the number of individuals, nevertheless the level of abundance in the autumn (September 1957) was equal to the abundance in the autumn of the preceding years. The winter reduction of $1957 / 58$ was again very considerable, and 1958 was in general a year of low levei of numbers (as it was in the case of the other species). The autumn increase in numbers that years was very slight, and the winter reduction of 1958/59 led to the maximum depression found throughout the whole study period.

The development of the population in the spring of 1959 is somewhat intensive. but numbers rise slowly up to the autumn and the autumn peak period is only very slightly greater than that of 1958. Attempts were made to connect this fact with the simultaneous mass appearance of $A$. agrarius (A ndrze je wski \& W r oc 1 a w ek, 1961).

The winter reduction of $1959 / 60$ is relatively slight and in July-August the po.. pulation attains numbers equal to those of 1956 and 1957. This is however the peak period of abundance in that year, and is followed by a reduction, while the autumn peak is never attained. The phenomenon is once again common to all three species and it is possible that it is caused by the heavy rainfull in the second half of the summer.

A further winter reduction reduced numbers to a very low level but as from the spring of 1961 numbers rise quickly, attaining as early as July an abundance equel to that in the auturnns $1955-1957$.

\section{B) A. agrarius}

From the aspect of abundance this species takes second place in the study area (Table 5). This picture is disturbed by the mass appearance which took place in 1959 , raising total numbers to the level of $C$. glareolus. The total amplitude of fluctuations in numbers is relatively wide, irrespective of the mass appearance.

The course taken by variations in numbers from 1955-1961 is as follows (Fig. 6):

The winter of $1955 / 56$ reduced the numbers of this species fairly intensively. The spring-summer increase in numbers produced in the autumn of 1956 a level slightly lower than that of C. glareolus. The winter reduction of $1956 / \overline{7} 7$ is slight]y weaker than that during this period in C. glareolus, so that as from January, 
throghout the whole summer period, the numbers of $A$. agrarius were higher than those of $C$. glareolus. The autumn increase in this abundance is relatively small (about $30 \%$ ) and is followed by the considerable winter reduction of $1957 / 58$, numbers in the unfavourable year 1958 being very low. The autumn peak period, although several times greater than the summer level, is also small. After a certain winter reduction, as from February 1959 there is a very rapid rise in the population leading to mass appearance of this species. In April the abundance of A. agrarius exceeds that of C. glareolus. From June to September the increase in numbers takes place in almost geometrical progression. If in June the mean figure was 16 animals, by July it was 39 and in August 60, and in September 82. Reduction is only slight up to October (mean figure for October $=77$ ), than becomes violent (in December the mean figure is only 10 , and in January 3 individuals).

The number of A. agrarius in 1960 is maintained on a very low level, and the autumn peak is expressed exceptionally weakly. The low level is maintained through the whole summer 1961, and exhibits a certain rise only in September.

The problem of the mass appearance of this species in 1959 was discussed in detail in the study by Andrzejewski \& Wroclawek (1961).

\section{C) A. flavicollis}

This is the least numerous species in the environment discussed (Table $\overline{0}$ ).

Its numbers are as a rule maintained on a relatively low level of several individuals (Fig. 6). With this state even small variations in numbers constitute relatively wide deviations (Table 5).

Table 5.

Mean abundances of each species of rodent.

\begin{tabular}{|c|c|c|c|c|}
\hline Year & \multicolumn{2}{|c|}{ C.glareolus } & A.agrar1us & A.flav1coll1s \\
\hline $1955 / 56$ & $24.14 \pm 0.81$ & $10.51 \pm 1.39$ & $7.78 \pm 0.95$ \\
$1956 / 57$ & $12.85 \pm 0.81$ & $16.27 \pm 1.31$ & $2.25 \pm 3.32$ \\
$1951 / 58$ & $9.61 \pm 0.79$ & $6.02 \pm 0.86$ & $0.96 \pm 4.68$ \\
$1958 / 59$ & $6.88 \pm 1.82$ & $19.50 \pm 0.29$ & $6.62 \pm 1.62$ \\
$1959 / 60$ & $7.52 \pm 2.45$ & $14.02 \pm 0.27$ & $3.20 \pm 2.91$ \\
$1960 / 61$ & $19.43 \pm 0.70$ & $3.72 \pm 2.82$ & $4.06 \pm 2.29$ \\
\hline Total & $12.19 \pm 1.76$ & $11.79 \pm 1.08$ & $4.22 \pm$ & \pm .61 \\
\hline
\end{tabular}

The higher level of abundance of this species was observed in October and November 1955, after which there was an intensive reduction up to May 1956. In the following years numbers are extremely low, falling at times almost to zero. The autumn increases in numbers are almost imperceptible. Only in 1959 is the level of numbers of $A$. flavicollis slightly higher, but the peak numbers occur earlier than is the case with $A$. agrarius (July) and in fact exceed those of C. glareolus at this time, although the maximum mean number is only 15 individuals.

\section{Changes in numbers of rodents}

The total number of rodents occurring, irrespective of the participation in this number of each species, may be of importance in economic questions (and also in biocenotic ones). 
Over the whole period of 6 year of observations, 3 years can be distinguished with average abundance of rodents - 1956, 1957 and 1961.

1958 and 1960 are distinguished by a very small number of these animals.

Finally in 1955 there was an exceptionally great abundance of rodents, owing to the mass appearance of $A$. agrarius, their mean number over the whole year thus giving a poor ilustration of the relations prevailing, since the main intensity of abundance occurred in the autumn months (Table 5).

The general variations in the numbers of these rodents were as follows (Fig. 6).

At the end of 1955 and in 1956 and 1957 there was a fairly great aburdance of the rodents. The dominant species is $C$. glareolus, with the numerous participation of $A$. agrarius. A. flavicollis in only numerous in 1955 .

Table 6.

Settling of rodents in the study area during the yearly cycle.

\begin{tabular}{|c|c|c|c|c|c|c|}
\hline \multirow[b]{2}{*}{ Sontho } & \multicolumn{2}{|c|}{ C. Blareolus } & \multicolumn{2}{|c|}{ A.agrarius } & \multicolumn{2}{|c|}{ A.Plav1:01:13 } \\
\hline & $\begin{array}{c}\text { ilo. of } \\
\text { rewcomers }\end{array}$ & $\begin{array}{c}\% \text { ot } \\
\text { settled }\end{array}$ & $\begin{array}{c}\text { io. of } \\
\text { newcomers }\end{array}$ & $\begin{array}{c}\vec{\omega} \text { of } \\
\text { settled }\end{array}$ & $\begin{array}{c}\text { Wo. of } \\
\text { newcomers }\end{array}$ & $\begin{array}{c}5 \text { of } \\
\text { settled }\end{array}$ \\
\hline$x$ & 166 & 55 & 27 & 48 & 97 & 58 \\
\hline$x !$ & 109 & 54 & 96 & 49 & 43 & 42 \\
\hline$X I I$ & 109 & 40 & 45 & 33 & 21 & 38 \\
\hline I & 63 & 51 & 15 & 27 & 12 & 42 \\
\hline II & 566 & 52 & 32 & 50 & 27 & 56 \\
\hline III & 61 & 51 & 49 & 37 & 28 & 32 \\
\hline IV & 55 & 58 & 47 & 47 & 26 & 34 \\
\hline$v$ & 93 & 57 & 61 & 36 & 54 & 37 \\
\hline$V_{I}$ & 141 & 49 & 118 & 36 & 80 & 53 \\
\hline VII & 134 & 51 & 132 & 57 & 86 & 43 \\
\hline VIII & 117 & 48 & 179 & 46 & 66 & 29 \\
\hline IX & 177 & 53 & 203 & 45 & 50 & 34 \\
\hline
\end{tabular}

The autumn peak periods of abundance of the rodents are distinct and exceed the spring minima by over twice as much.

1958 is distinguished by a very small number of the rodents; the proportion of spring minimum to autumn peak is similar to that of the preceding years.

1959 from the spring onwards was distinguished by a very rapid increase in numbers, chiefly at the expense of $A$. agrarius and $A$. flavicollis, to such an extent that in the autumn the level of abundance of the rodents exceeded the maxima in preceding years by over twice as much. In October and November there was a violent reduction in numbers.

In 1960 after a fairly good spring increase in abundance, an inhibition of increase occured in the summer and hence in the autumn the norma? peak was not formed. 
1961 was distinguished by an increase in the numbers of the rodents, chiefly of C. glareolus; a situation similar to that in 1955-1957 was therefore created.

\section{EXCHANGE OF INDIVIDUALS}

The direct formation of variations in numbers on a defined small area (our study area) takes place through the processes of incoming, settlement and disappearance of individuals.

\section{Incoming}

New individuals, not hitherto registered, were caught in the study area throughout the whole observation period. The high degree of trappability and hence accurate marking of the settled part of the population makes it possible to assume that during the period in which there is no reproduction of the rodents, these new individuals were either immigrants or migrants passing through the study area. During the breeding season, as stated previously, these may be newly-born individuals in the study area. No exact observations of the age of the animals captured were made, kut judging by the size, in the reproduction season also the basic number of individuals entering the area consist of older animals, and not those which have only just left the nests.

The number of rodents passing through the study area is certainly greater than the number of new animals caught in the traps. This is caused on the one hand by the short time for which the traps are set ( 2 days per week) and on the other by the probability of the mice being caught (see Section VI). The new individuals caught (newcomers) form a group composed of respective percentages (Table 6) of immigrants settling in and migrants passing through the study area.

The chances of catching individuals settling in are far greater than of catching migrating individuals, owing to the repeated opportunities $c$ : this first group coming into contact with the traps. They are further increased by the bait which is placed on the site of the traps on the days when no trapping is done.

The number of migrating individuals caught depends directly on the actual number of migrants and on the probability of their encountering the traps (the time for which they are set and their density), the time during which these individuals have the opportunity of contacting the traps being relatively short owing to the brief period which the migrating individuals spend in the study area. 
It may therefore be assumed that variations in the numbers of migrants passing through the area will be only proportionally and faithfully registered by limited, in numbers and time, but constant setting of traps. For this reason it would seem that despite the fact that settled rodents

Table 7.

Correlation between the number of immigrating individuals (x) and settled individuals $(\mathrm{y})$ of $\mathrm{C}$. glareolus in the study area.

\begin{tabular}{|c|c|c|c|c|c|c|c|c|c|c|c|c|c|c|}
\hline$y$ & $\begin{array}{l}\sim \\
1 \\
0\end{array}$ & in & $\begin{array}{l}\infty \\
1 \\
0\end{array}$ & $\begin{array}{l}0 \\
1 \\
\text { an }\end{array}$ & $\begin{array}{l}\Xi \\
\therefore \\
\therefore\end{array}$ & $\begin{array}{l}\approx \\
\therefore\end{array}$ & $\begin{array}{l}\stackrel{O}{v} \\
1 \\
n\end{array}$ & $\begin{array}{l}\tilde{\sim} \\
\vdots \\
\tilde{\sim}\end{array}$ & $\begin{array}{l}\stackrel{0}{\sim} \\
\dot{N} \\
\tilde{N}\end{array}$ & $\begin{array}{l}\stackrel{2}{\sim} \\
\therefore \\
\therefore\end{array}$ & $\stackrel{\text { s }}{\dot{m}}$ & $\begin{array}{l}n \\
1 \\
7\end{array}$ & $\begin{array}{l}\stackrel{\infty}{\sim} \\
1 \\
\stackrel{0}{0}\end{array}$ & $\begin{array}{l}5 \\
1 \\
9\end{array}$ \\
\hline $0-1$ & 3 & 4 & 1 & & & & & & & & & & & \\
\hline $2=3$ & $t$ & 8 & 6 & 3 & 2 & & 1 & & 1 & & 1 & 1 & & \\
\hline $4-5$ & & 4 & 1 & 7 & 2 & 1 & & 1 & 2 & & 1 & & & 1 \\
\hline $6-7$ & & & 3 & 1 & 2 & & 2 & & & 1 & & & & \\
\hline $8-9$ & & & 1 & & & & & 1 & 2 & & & & & \\
\hline $10-19$ & & & & 1 & & , & & 1 & & 1 & 1 & & & \\
\hline
\end{tabular}

Table 8.

Correlation between the number of immigrating individuals ( $x$ ) and settled individuals $(y)$ of $A$. agrarius in the study area.

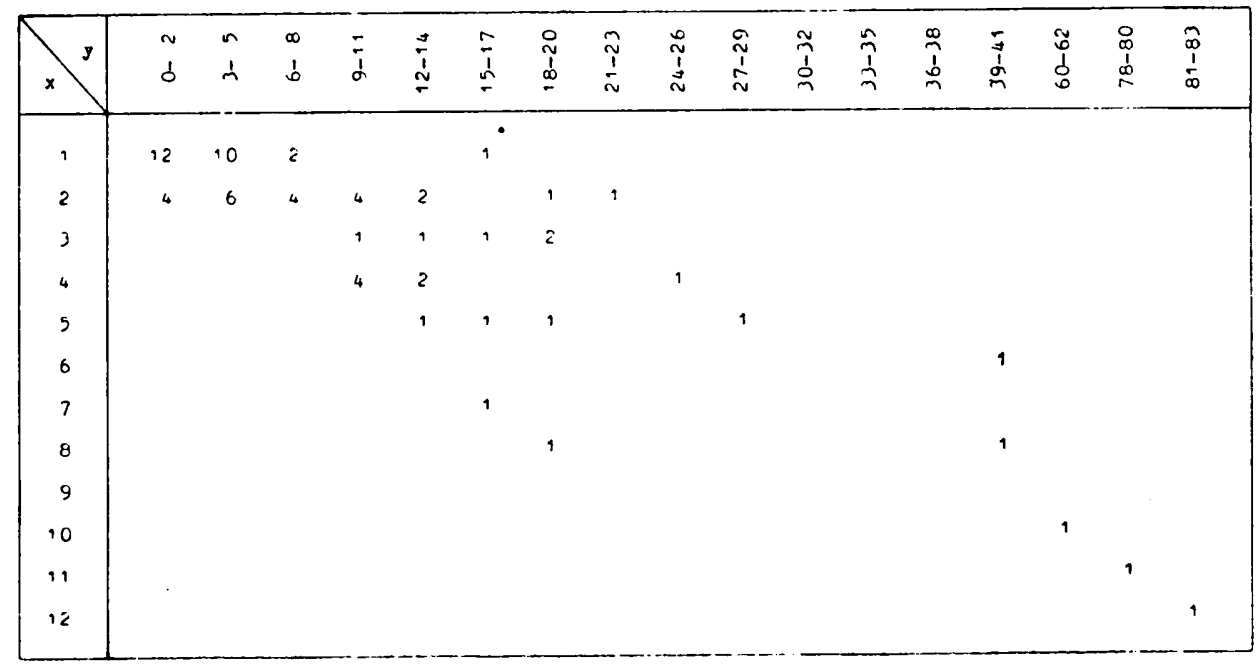

form part of it, the group of new individuals is a certain indication of the process of incoming of migrating animals into the study area, and therefore simultaneously expresses the intensity of penetration of the area by the migrants. 
The number of rodents entering the study area in a given period is in principle directly in proportion to the number of settled rodents during this period.

This is indicated by the statistically significant and high coefficients of correlation between the mean number of settled animals in each month and the mean number of animals incoming into the study area in these months, calculated for $C$. glareolus $(r=0.46)$ and $A$. agrarius $(r=0.89)$. Calculation of the correlation was not made for $A$. flavicollis on account of the low numbers of the species (Table $7,8)$.

Since the migrating and settled individuals form the abundance of the population it may therefore be stated, that the total number of migrating animals measured by the number of animals entering a defined space in a unit of time is in principle proportional to the total numbers of the population.

At the same time the incomplete correlation of these two values (of immigrant and settled animals) that is, the values of coefficients diverging from 1.00 , indicate that these proportions vary in time, and therefore immigration does not give a complete picture of numbers.

Thus C. glareolus has a coefficient of correlation lower than that of A. agrarius $(0.46$ and 0.89$)$, that is, this species is characterised by a greater

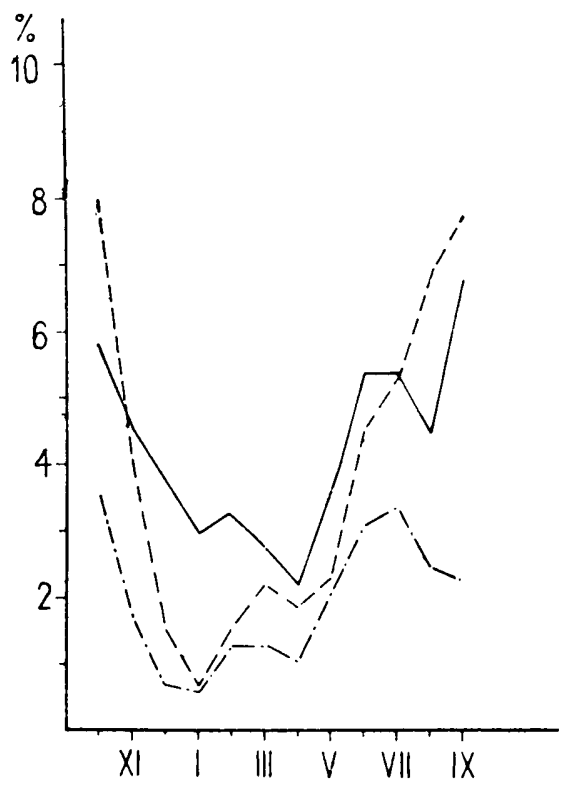

Fig. 7. Intensity of immigration of rodents into the study area during the yearly cycle. Axis $\mathrm{x}-$ months, axis $\mathrm{y}-\%$ of immigrating individuals in relation to number of resident rodents. Symbols for species as in Fig. 2.

variability in the number of mice entering in relation to the settled mice than $A$. agrarius. This is easy to see in the correlation tables (Table 7,8 ).

The materials accumulated in this study make it possible to show the influence of the climatic yearly cycle as one of the causes of incompleteness of correlation.

The intensity of immigration $\left(V_{n}\right)$ may be expressed by the percentage formed during the given period by the individuals entering the area $\left(A_{n}\right)$ in relation to the number of settled mice $\left(X_{n}\right)$ :

$$
v_{n}=\frac{A_{n} \cdot 100}{X_{n}}
$$


The distribution of this index in the species examined, calculated jointly for all the observation years in each month of the year indicates that in the winter months the intensity of immigration is reduced, after which it increases as from the spring onwards, to attain its highest value in the autumn period (Fig. 7).

\section{Settlement}

A certain part of immigrating individuals into the study area are later repeatedly recaptured. An analysis of the distributions of length of stay showed (see Section VI) that the mice which remained in the study area longer than one week can be treated as having settled in it.

Table 9.

Correlation between number of settling individuals $(x)$ and immigrating individuals $(\mathrm{y})$ of $C$. glareolus $(\mathrm{r}=0.86)$.

\begin{tabular}{|c|c|c|c|c|c|c|c|c|c|c|c|c|}
\hline$x^{y}$ & 1 & 2 & 3 & 4 & 5 & 6 & 7 & 8 & 9 & 10 & 11 & 12 \\
\hline 1 & 2 & 4 & & & 1 & & & & & & & \\
\hline 2 & & 1 & 10 & 4 & 3 & 2 & & & & & & \\
\hline 3 & & & & 10 & 6 & 1 & 1 & & & & & \\
\hline 4 & & & & 1 & 1 & 3 & 2 & 3 & & & 1 & \\
\hline 5 & & & & & & 2 & 2 & 1 & 1 & 1 & & \\
\hline 6 & & & & & & & 1 & & & 1 & & 1 \\
\hline 7 & & & & & & & & 1 & & & 1 & 1 \\
\hline 8 & & & & & & & & & & & & 1 \\
\hline
\end{tabular}

Table 11.

Correlation between settling individuals (x) and settled individuals of C. glareolus $(\mathrm{r}=0.64)$.

\begin{tabular}{|c|c|c|c|c|c|c|c|c|c|c|c|}
\hline$x$ & d & $\begin{array}{l}n \\
!\end{array}$ & $\frac{5}{\infty}$ & $\frac{n}{1}$ & $\frac{\sigma}{b}$ & $\underset{\sim}{\tilde{d}}$ & 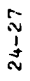 & $\stackrel{\bar{m}}{\stackrel{\infty}{\sim}}$ & $\stackrel{\sim}{\sim}$ & 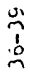 & d \\
\hline 1 & 8 & & & & & & & & & & \\
\hline 2 & 3 & 9 & 4 & 2 & & 1 & & & & & \\
\hline 3 & 2 & 6 & 4 & 3 & & & 2 & & & 1 & \\
\hline 4 & & 1 & 5 & 1 & & 1 & 1 & 1 & & & 1 \\
\hline 5 & & & 2 & 1 & 1 & 1 & 1 & 1 & & & \\
\hline 6 & & & & 1 & & & 9 & 1 & & & \\
\hline 7 & & & & & 1 & & & 2 & & & \\
\hline 8 & & & & & & 1 & & & & & \\
\hline
\end{tabular}

Table 10.

Correlation between number of settling individuals $(x)$ and immigrating individuals (y) of $A$. agrarius ( $\mathrm{r}=0.91$ ).

\begin{tabular}{|c|c|c|c|c|c|c|c|c|c|c|c|c|c|c|c|c|c|c|c|c|c|c|}
\hline$x$ & 1 & 2 & 3 & 4 & 5 & 6 & 7 & 8 & 9 & 10 & 11 & 12 & 13 & 14 & 15 & 16 & 17 & 18 & 19 & 20 & 21 & 22 \\
\hline 1 & 7 & 16 & 3 & & & & & & & & & & & & & & & & & & & \\
\hline 2 & & 3 & 9 & 5 & & 1 & & & & & 1 & & & & & & & & & & & \\
\hline 3 & & & 1 & 3 & 2 & 1 & & 1 & & & & & & & & & & & & & & \\
\hline 4 & & & & & & 1 & 3 & 1 & . & & & & & & & & & & & & & \\
\hline 5 & & & & & & & & 2 & 2 & 1 & & & 1 & & & & & & & & & \\
\hline 6 & & & & & & & & & & & & & & & & & & & & & & \\
\hline 7 & & & & & & & & & 1 & & & & & & & 1 & & & & & & \\
\hline 8 & & & & & & & & & & & & & & & & & & & & & 1 & \\
\hline 9 & & & & & & & & & & & & & & & & & & & & & & \\
\hline 10 & & & & & & & & & & & & & & & & & & & & & & \\
\hline 11 & & & & & & & & & & & & & & & & 1 & & & 1 & & & \\
\hline 12 & & & & & & & & & & & & & & & & & & & & & & 1 \\
\hline
\end{tabular}


The number of animals settling in is principle proportional to the number of immigrating animals. This is indicated by the high degree of correlation between the mean numbers of immigrating individuals in one half of the mice; in different months, and by the corresponding numbers settling in, both in the case of $C$. glareolus $(\mathrm{r}=0.86)$, and A. agrarius $(\mathrm{r}=0.91)$ (Table 9,10$)$.

It would seem that this situation may be due to two causes:

1. Among the animals caught for the first time a considerable percentage is formed by individuals factually settled. In the case of C. glareolus, for instance, this varies within limits of $33-76 \%$ in different years, calculated for the whole of the material is $35 \%$ for females and $38 \%$ [?: males (difference not statistically significant (Table 4 and Section V).

Table 12.

Correlation between settling individuals $(\mathrm{x})$ and settled individuals of $A$. agrarius (́y) $(\mathrm{r}=0.84)$.

\begin{tabular}{|c|c|c|c|c|c|c|c|c|c|c|c|c|c|c|}
\hline$x^{y}$ & $\hat{d}$ & ! & $\bar{d}$ & $\begin{array}{l}n \\
i \\
\sim\end{array}$ & 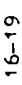 & $\underset{\tilde{n}}{\stackrel{\alpha}{\sim}}$ & $\begin{array}{l}\tilde{n} \\
\vdots \\
\tilde{n}\end{array}$ & 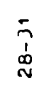 & 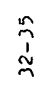 & $\begin{array}{l}\hat{i} \\
\hat{n}\end{array}$ & $\begin{array}{l}\vec{z} \\
\vec{d}\end{array}$ & ؛े & $\begin{array}{l}\hat{i} \\
\stackrel{b}{r}\end{array}$ & $\begin{array}{l}0 \\
\infty \\
\vdots \\
\infty\end{array}$ \\
\hline 1 & 16 & 4 & 1 & 2 & & & & & & & & & & \\
\hline 2 & 6 & 7 & 3 & 2 & 2 & 1 & & & & & 1 & & & \\
\hline 3 & & 2 & 3 & 1 & , & 1 & & & & & & & & \\
\hline 4 & & & 1 & 2 & , & 1 & & & & & & & & \\
\hline $\begin{array}{l}5 \\
6\end{array}$ & & & 2 & 2 & । & , & & & & & & & & \\
\hline 7 & & & & & , & & & 1 & & & & & & \\
\hline $\begin{array}{l}\text { } \\
\text { g }\end{array}$ & & & & & & & & & & & & & a & \\
\hline 10 & & & & & & & & & & & & & & \\
\hline 11 & & & & & & & & & & 1 & & 1 & & \\
\hline & & & & & & & & & & & & & & r \\
\hline
\end{tabular}

2. The migrant individuals incoming onto a defined area may exert a certain "pressure" on the process of settling in; this would mean that the more mice that seek for a place to settle in, the more mice find this place.

The participation of these two causes in the process of settling in remains to be further investigated.

The correlations mentioned in the previous section between the number of immigrant and settled animals and the high degrees of correlations referred to above between the number of immigrating and settling animals, define the high degree of correlation between the number of animals settling in and those already resident (with C. glareolus, $\mathrm{r}=0.64, \mathrm{~A}$. agrarius, $\mathrm{r}=0.84$ ) (Table 11,12). This means that in months with a high level of numbers of settled mice, the number of mice settling in is also high), 
If the number of individuals settling in is expressed in percentages of the number of settled individuals in the study area, this calculation being made for each month in the yearly

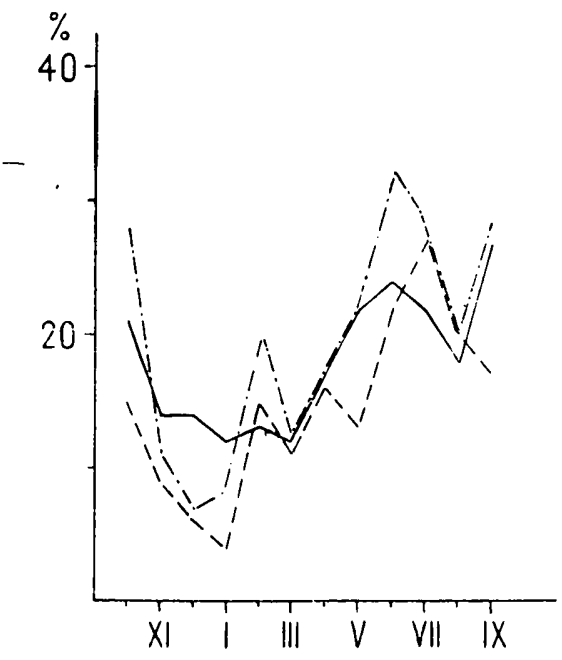

Fig. 8. Intensity of settling of the rodents over the yearly cycle. Axis $\mathrm{x}$ - months, axis $\mathrm{y}-\%$ settling in relation to settled. Symbols for species as in Fig. 2. cycle jointly for all the observation years, then we can see that in relation to the number of settled individuals we have a relatively low degree of settlement in the winter months, after which it increases to attain its highest level in the autumn. This process takes a similar course in all three species (Fig. 8).

The fact is obvious, since with the constant process of disappearance of animals from the settled part of the population caused by mortality and transition to the group of migrants, the high level of numbers of the settled animals may be attained when there is a high degree of settling.

The high degree of correlation between settling and immigrating animals indicates that there are no great variations in the process of transition from the migrating state to the settled state. Similarly no distinct regularities in this process are observed during the yearly cycle (Table 6).

\section{Disappearance}

Different animals belonging to the group of settled individuals ceases to be repeatedly captured at a certain moment. I have taken this moment as the date of disappearance of the animal from he study area, with the reservations resulting from trappability (Section V).

I have also emphasised that it is impossible, with the method used, to distinguish between disappearance of the animal from the study area due of its death or due to emigration, with the exception of those animals which begin to be caught again after a non-fortuitously long interval (Section V). Only in the case of these latter individuals it is possible to conclude that they emigrated from the study area and then returned to it.

The indices of correlation calculated between the mean numbers of individuals disappearing for a week in each month of the year, and the corresponding numbers both of immigrant and of settling individuals, are 
positive and statistically significant. They are: for $C$. glareolus, $\mathrm{r}=0.56$ and 0.49 , for $A$. agrarius, $\mathrm{r}=0.70$ and 0.86 (Table $13,14,15,16$ ).

Table 13.

Correlation between the number of disappearing $(x)$ and immigrating $(y)$ individuals of $C$. glareolus $(r=0.56)$.

\section{Table 15.}

Correlation between number of settling : $x$ ) and disappearing $(\mathrm{y})$ individuals of C. $g l a-$ reolus $(=0.49)$.

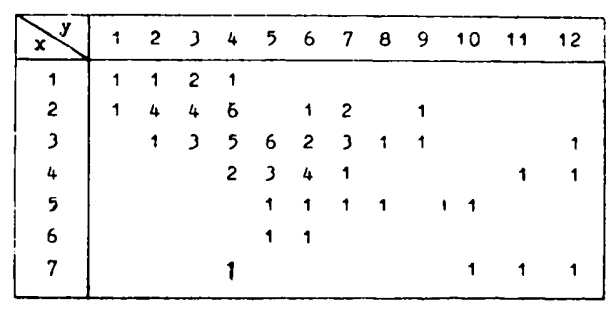

\begin{tabular}{|c|ccccccc|}
\hline$x$ & 1 & 2 & 3 & 4 & 5 & 6 & 7 \\
\hline 1 & 2 & 4 & 1 & & & & \\
2 & 2 & 6 & 8 & 3 & 1 & & \\
3 & 1 & 5 & 7 & 2 & 2 & & 1 \\
4 & & 3 & 2 & 2 & 2 & 2 & \\
5 & & & 4 & 2 & & 1 \\
6 & & 1 & & & 1 & 1 \\
7 & & & 1 & & 1 & 1 \\
8 & & & & 1 & & & \\
\hline
\end{tabular}

Table 14.

Correlation between the number of disappearing $(\mathrm{x})$ and immigrating $(\mathrm{y})$ individuals of A. agrarius $(\mathrm{r}=0.70)$.

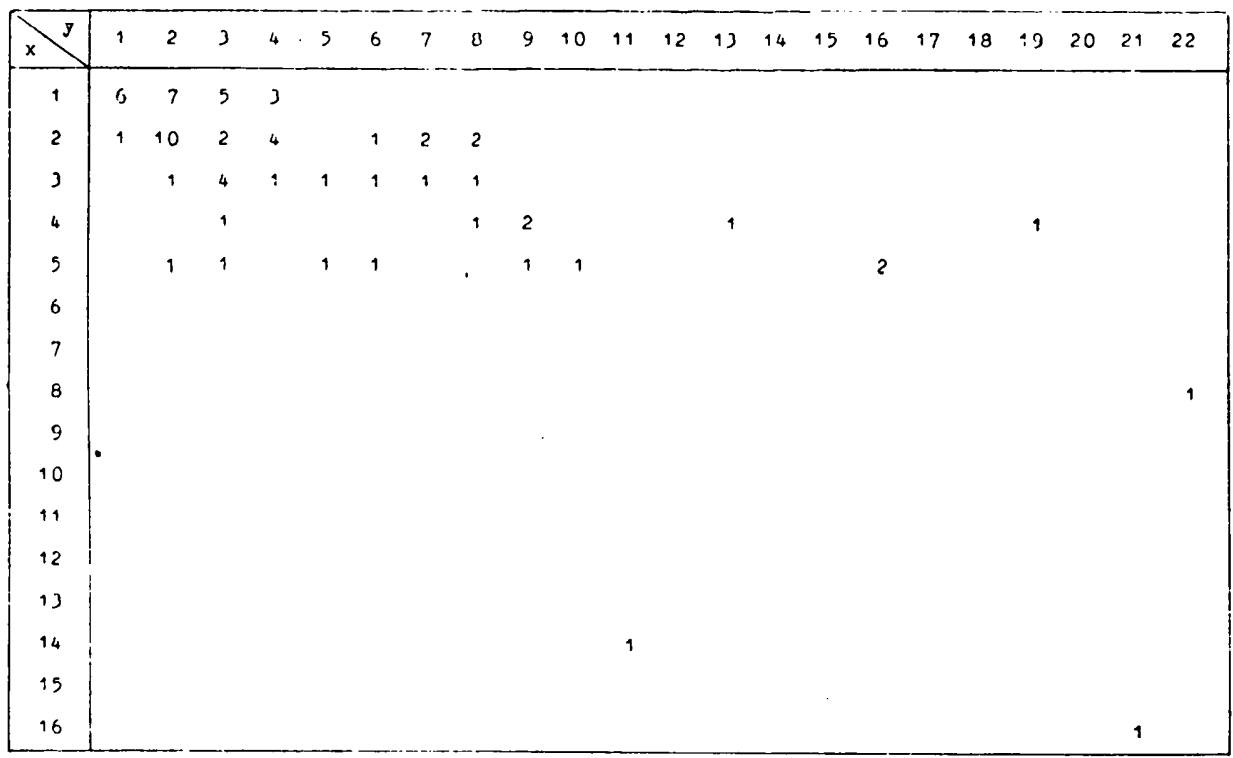

If the number of migrating animals in the population increases by the transition of the settled part of the population into a state of migration. ihen on the one hand the number of animals entering the study area should increase, and on the other the number of animals which disappeared from the study area (transferred to a state of migration) should increase. 
Table 16.

Correlation between number of settling $(x)$ and disappearing ( $y$ ) individuals of A. agrarius $(\mathrm{r}=0.86)$.

\begin{tabular}{|c|c|c|c|c|c|c|c|c|c|c|c|c|c|c|c|c|c|}
\hline$x^{y}$ & 0 & , & 2 & 3 & 4 & 5 & 6 & 7 & 8 & 9 & 10 & .11 & 12 & 1) & 14 & 15 & 16 \\
\hline 0 & 11 & 9 & 3 & & , & & & & & & & & & & & & \\
\hline , & 7 & 8 & 3 & 1 & 1 & & & & & & & & & 1 & & & \\
\hline 2 & 2 & 3 & 2 & & 1 & & & & & & & & & & & & \\
\hline 3 & & 2 & 2 & & 1 & & & & & & & & & & & & \\
\hline 4 & & 1 & & 4 & 1 & & & & & & & & & & & & \\
\hline 5 & & & & & & & & & & & & & & & & & \\
\hline 6 & & & & & 2 & & & & & & & & & & & & \\
\hline 7 & & & & & & & & & & & & & & & & & \\
\hline 8 & & & & & & & & & & & & & & & & 1 & \\
\hline 9 & & & & & & & & & & & & & & & & & \\
\hline 10 & & & & 1 & 1 & & & & & & & & & & & & \\
\hline 19 & & & & & & & & 1 & & & & & & & & & \\
\hline
\end{tabular}

The indices of correlation therefore indicate that immigration and disappearance (if not caused by mortality) are synchronised in time as an expression of the general tendency to redistribution of the animals in a given period.

The fairly low value of the indices of correlation between the numbers of disappearing individuals and the corresponding numbers of immigrating and settling individuals indicates the divergences from this rule which

Table 17.

Correlation between number of disappearing (x) and settled (y) individuals of C. glareolus $(\mathrm{r}=0.63)$.

\begin{tabular}{|c|c|c|c|c|c|c|c|c|c|c|c|}
\hline 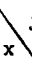 & $\begin{array}{l}m \\
d\end{array}$ & t & $\frac{5}{1}$ & $\stackrel{n}{\stackrel{1}{\prime}}$ & $\frac{a}{b}$ & $\underset{\sim}{\tilde{d}}$ & $\begin{array}{l}\tilde{v} \\
\underline{v} \\
\vec{v}\end{array}$ & $\begin{array}{l}\bar{v} \\
\dot{1} \\
\text { v }\end{array}$ & $\begin{array}{c}\text { In } \\
i \\
\sim \\
\sim \\
\sim\end{array}$ & $\begin{array}{c}\stackrel{a}{2} \\
\mathfrak{b} \\
\end{array}$ & $\begin{array}{l}\text { d } \\
d\end{array}$ \\
\hline 1 & 10 & 9 & 3 & 2 & & & 1 & 1 & & 1 & \\
\hline 2 & 2 & 7 & 9 & 2 & 2 & & & & & & \\
\hline 3 & & 2 & 1 & 3 & 1 & 1 & 1 & 2 & & & \\
\hline 4 & & & & 1 & & 2 & 1 & & & & \\
\hline 5 & & & & & & & 1 & 1 & & & 1 \\
\hline 6 & & & & & & 1 & 1 & 1 & & & \\
\hline
\end{tabular}
may be caused both by the mortality of settled animals (the per-centage of animals which died in the group of disappearing rodents), not connected in time with the migratoriness of the population, and by fortuitous divergences in the intensity of immigration and disappearance.

It may also be noticed that the corresponding indices are lower for C. glareolus than for A. agrarius (Table 13, 14, 15, 16).

The correlation connection between disappearance and immigration and settling also gives the correlation of the number of disappearing animals with the number of settled animals in the study area (Table 17,18 ). 
Table 18.

Correlation between the number of disappearing $(x)$ and settled $(y)$ individuals of A. agrarius $(\mathrm{r}=0.86)$.

\begin{tabular}{|c|c|c|c|c|c|c|c|c|c|c|c|c|c|c|c|c|c|}
\hline$x$ & $\begin{array}{l}N \\
\dot{1}\end{array}$ & in & $\begin{array}{l}\infty \\
b\end{array}$ & $\bar{j}$ & $\stackrel{ \pm}{\stackrel{1}{\simeq}}$ & $\stackrel{1}{n}$ & 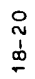 & $\frac{\hat{I}}{\tilde{N}}$ & $\begin{array}{l}\stackrel{0}{\sim} \\
\stackrel{+}{\sim}\end{array}$ & 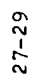 & $\stackrel{\widetilde{n}}{\grave{c}}$ & $\stackrel{n}{\frac{1}{n}}$ & 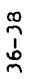 & 㐬 & $\begin{array}{l}\tilde{o} \\
d \\
d\end{array}$ & 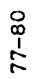 & $\begin{array}{l}\hat{\infty} \\
\frac{1}{\infty}\end{array}$ \\
\hline 1 & 17 & 13 & 4 & 5 & 2 & 2 & & 2 & & & & & & & & & \\
\hline 2 & 1 & 1 & & 2 & 4 & 1 & 1 & & & & & & & & & & \\
\hline 3 & & & & 1 & 1 & & 1 & & & & & & & & 1 & & \\
\hline 4 & & 1 & & & 1 & 1 & 2 & 1 & & 9 & & & 1 & & & & \\
\hline 5 & & & & & & & & & & & & & & & & & \\
\hline 6 & & & & & & & & & & & & & & & & & \\
\hline 7 & & & & & & & & & & & & & & & & & 1 \\
\hline 8 & & & & & & & & & & & & & & & & & \\
\hline 9 & & & & & & & & & & & & & & & & & \\
\hline 10 & & & & & & & & & & & & & & & & & \\
\hline 11 & & & & & & & & & & & & & & & & & \\
\hline 12 & & & & & & & & & & & & & & 1 & & & \\
\hline 13 & & & & & & & & & & & & & & & & & \\
\hline 14 & & & & & & & & & & & & & & & & & \\
\hline 15 & & & & & & & & & & & & & & & & 1 & \\
\hline
\end{tabular}

If the intensity of disappearance is characterised by the percentage of disappearing, in relation to the number of settled animals in each month jointly for the whole observation period (Fig. 9), then we can see that the variations in this intensity over the yearly cycle are not very violent. Reduction of the intensity of disappearance occurs in the winter period (January, February), while in the summer and autumn months in all the species investigated, with random fluctuations in intensity of disappearance, it is maintained on a certain defined level. An increase in disappearance can be observed in the late autumn (November, December).

It is possible that the latter phenomenon is caused by the more intensive mortality of the rodents during the winter reduction.

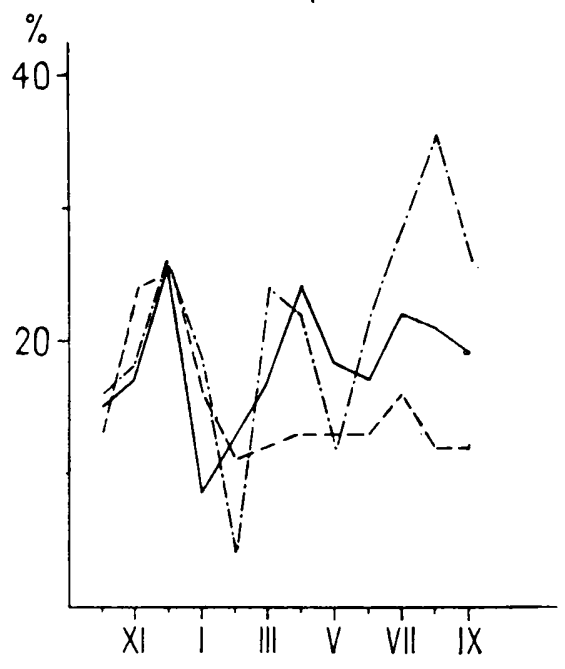

Fig. 9. Intensity of disappearance of rodents during the yearly cycle. Axis $\mathrm{x}$ - months, axis $\mathbf{y}-\%$ of animals disappearing in relation to settled individuals. Symbols for species as in Fig. 2.

4. Rotation and variations in the degree of settledness of the population

The constant process of settlement and disappearance of animals in the study area causes a constant interchange among the individuals settled in 
Table 19.

Correlation between the number of settled $(x)$ and settling + disappearing $(y)$ individuals of $C$. giareolus $(r=0.73)$.

\begin{tabular}{|c|c|c|c|c|c|c|c|c|c|c|c|c|c|c|}
\hline$x$ & $\begin{array}{l}\sim \\
d\end{array}$ & $n$ & $\begin{array}{l}\infty \\
b\end{array}$ & $\frac{5}{d}$ & $\stackrel{\Xi}{\check{1}}$ & In & $\begin{array}{l}\stackrel{O}{N} \\
\vdots \\
\infty\end{array}$ & $\frac{\tilde{i}}{\tilde{I}}$ & $\underset{\sim}{\stackrel{0}{\sim}}$ & 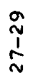 & $\overline{\hat{\jmath}}$ & $\stackrel{n}{\stackrel{n}{\sim}}$ & 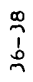 & I \\
\hline 0 & 1 & & & & & & & & & & & & & \\
\hline 1 & 4 & 1 & 1 & & & & & & & & & & & \\
\hline 2 & & 6 & & 1 & & & & & & & & & 1 & \\
\hline 3 & & 4 & 6 & 3 & 2 & & & & & • & & & & \\
\hline 4 & & 1 & 2 & 4 & 2 & & 9 & & & & 1 & & & \\
\hline 5 & & 1 & 4 & 1 & 1 & & & 1 & & & & & & \\
\hline 6 & & & & 2 & 3 & 9 & 1 & & 2 & & & & & \\
\hline 7 & & & & & & 1 & 1 & & & & 1 & & & \\
\hline 8 & & & & & & & & & 1 & & & & & 1 \\
\hline 9 & & & & & & & & 1 & 1 & & & & & \\
\hline 10 & & & & & & & & 1 & 1 & & 1 & & & \\
\hline 11 & & & & & & & & & & 1 & & & & \\
\hline 12 & & & & & & & & & & & 1 & & & \\
\hline
\end{tabular}

'Table 20.

Correlation between the number of settled $(x)$ and settling t- disappearing $(y)$ in 3 ividuals of $A$. agrarius $(\mathrm{r}=0.93)$.

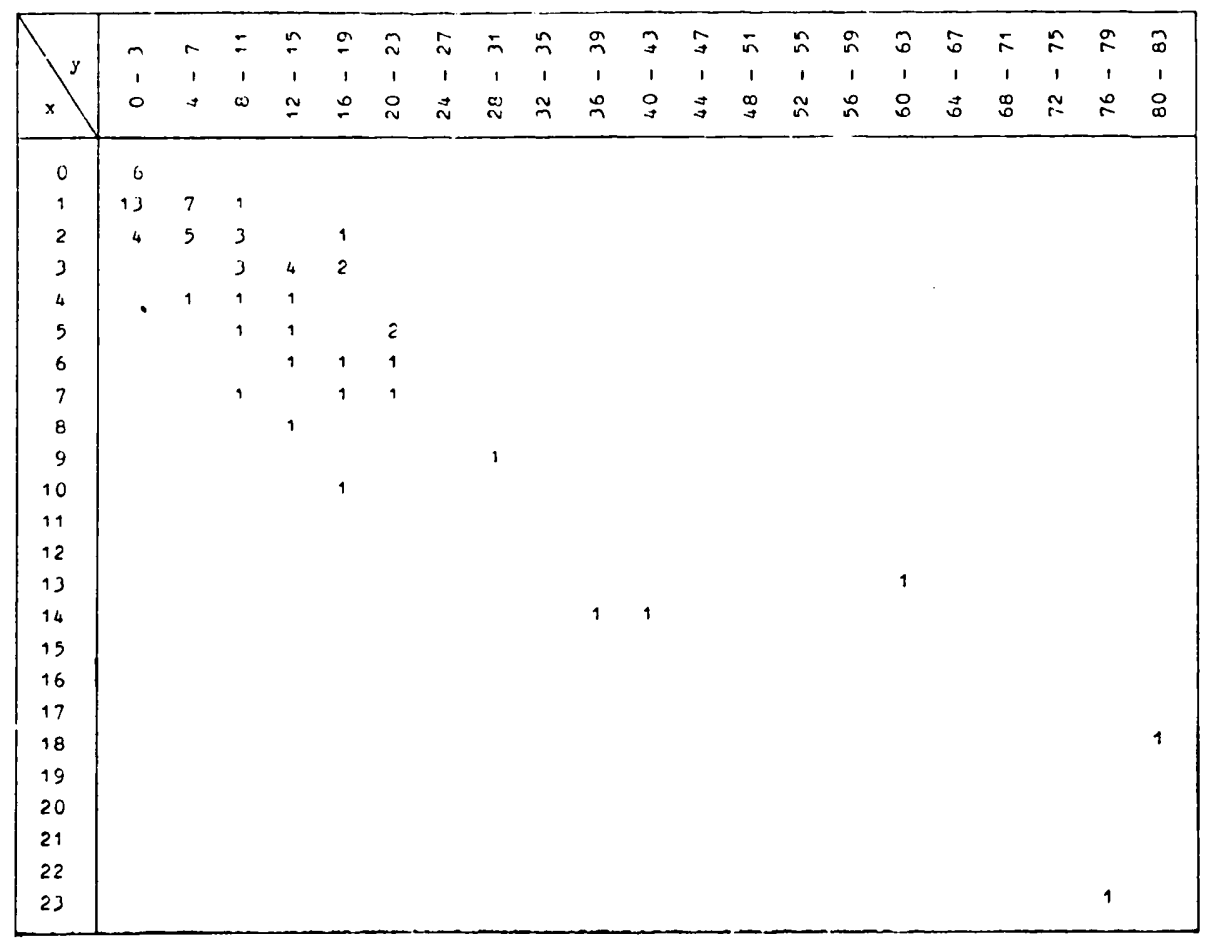


Table 21.

Correlation between the number of settled individuals $(x)$ and intensity of rotation ( $y)$ in C. glareolus $(\mathrm{r}=-0.56)$.

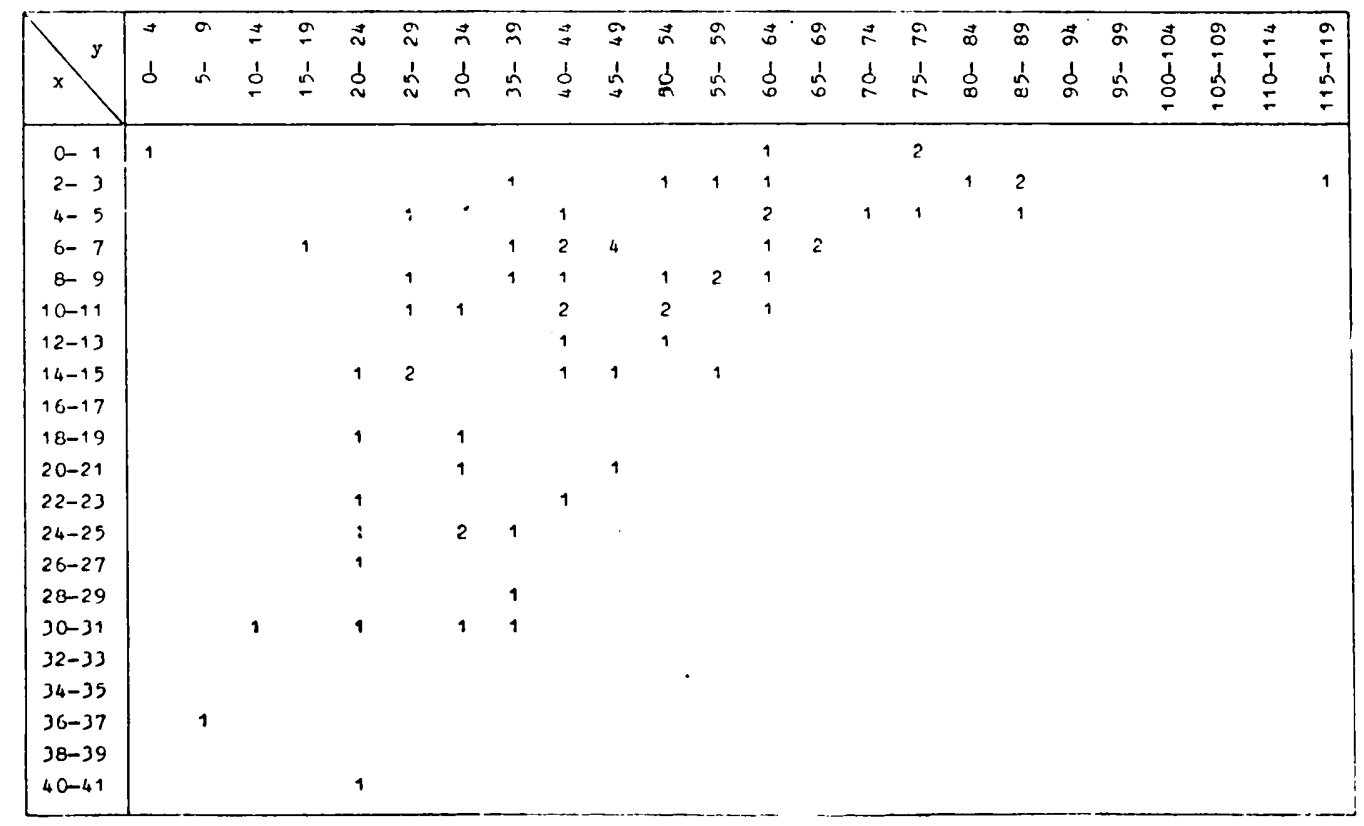

Table 22.

Correlation between the number of settled individuals $(x)$ and intensity of rotation ( $y$ ) in A. agrarius $(\mathrm{r}=-0.21)$.

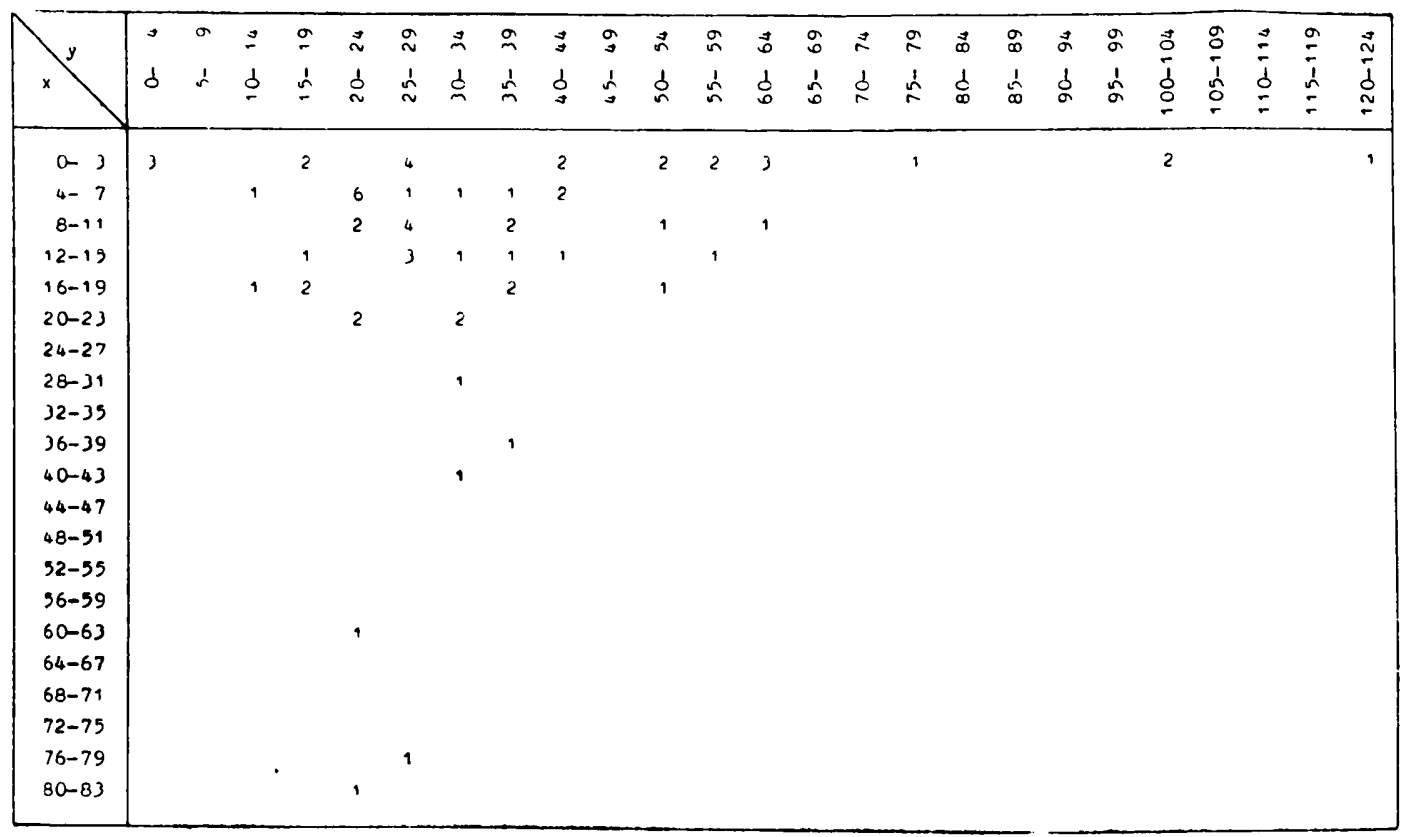



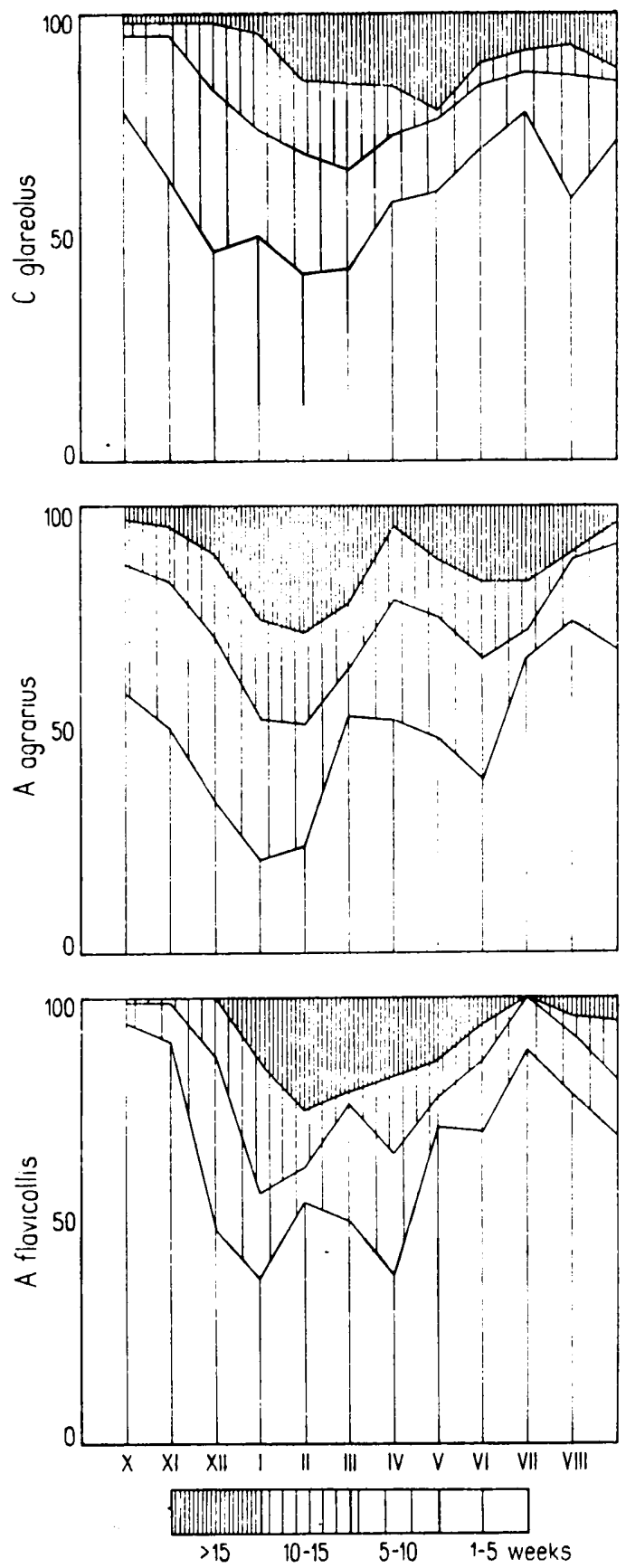

Fig. 10. Variations in the degree of residency of the population during the yearly cycle. On axis $\mathbf{x}-$ months, axis $\mathrm{y}$ - percentages formed in the population by animals with a given length of residence in the study area. The length of residence of each class is marked at the bottom of the figure. 
this area - rotation of the settled part of the population. We can speak of the intensity of rotation, meaning by that the ratio of animals interchanging (settling in + disappearing) to the number of settled animals in a given period, expressed in percentages.

$$
R_{n}=\frac{\left(a_{n}+b_{n}\right) \cdot 100}{X_{n}}
$$

A positive correlation is observed between the sum of individuals settling in and disappearing, and the number of settled mice in the study area.

This is understandable in view of the correlation connection of each of these processes separately with the number of settled mice in the study area. Jointly the coefficients of correlation are very high, those for A. agrarius $(\mathrm{r}=0.93)$ being higher than those for $C$. glareolus $(\mathrm{r}=0.73)$ (Table 19, 20).

A negative correlation of the index of rotation with the number of settled mice in the study area is, however, observed. This correlation is statistically real in the case of $C$. glareolus $(\mathrm{r}=-0.56)$, with $A$. agrarius it also possesses a negative value, but is not statistically real $(\mathrm{r}=-0.21)$. The result of these calculations means, at least for $C$. glareolus, that with a low level of numbers of the settled part of the population the intensity of interchange of individuals is relatively greater than with a high level (Table 21, 22).

This means that the high degree of settledness favours or evokes higher population numbers (this view is held by Andrzejewski \& W r o cł a w e k, 1961) or that the high level of numbers causes increased settledness of the population (the view held by $\mathrm{N}$ a u m o v, 1956).

It is obvious that the rotation of individuals affects the degree of settledness of the population. At a given moment there may be relatively many animals among the settled individuals which have lived in the study area for a long time, or else a relatively large number of animals which have only recently settled in the area. The composition of the population from the aspect of the time in which the individuals belonging to it settled in may be characterised by the percentage of these groups (Fig. 10).

The distribution of the times of stay of the settled individuals has an exponential character (see Section V), which means that different grours of individuals characterised by a defined length of stay in the study area, disappear in proportion to their numbers and that there is no defined time in which the particular individual would be settled. Disappearance affects all the groups of animals in a different period of settledness to an equal degree. 
Hence if rotation is relatively low during some period, then with thee re lapse of time accumulation of individuals with a longer period of settled-- 1ness occurs in the population.

This explains the fact that during the yearly cycle the classes of indi-- ividuals with the longest period of settlement appear after a low level off of winter rotation, that is, in the spring period (Fig. 10).

This phenomenon takes a slightly different course with different spe-- :cies. C. glareolus possesses the smallest fluctuations in the percentage off of groups which have been settled for a considerable time. The greates:t: i: fluctuations are exhibited by A. agrarius, where the population is mosit it settled in January and February. The greatest percentage of individualss $\mathrm{S}$ only recently settled occurs in the autumn in the population of all thee $\mathrm{e}$ species. Increased immigration during the early spring period also affectss $s$ the renewal of the population (Fig. 10).

Attention was drawn to the high degree of settledness of the populatiom 1 during the period of mass appearance of A. agrarius in 1959 in the study $\Rightarrow$ by A ndrzejews ki \& Wrocławe k (1961).

The finding of a correlation between the numbers of immigrating, setti- ing and disappearing animals and the number of settled animals in a given 1 area makes it possible to assume a high degree of interdependence bet- ween all these elements in the populations of small rodents.

The average time of settlement of the animals in the given area is the factor, which, on the one hand, determines abundance and the composition of the settled part of the population, and on the other hand is itself modified by the process of rotation of individuals. Settlement and disappearance, and indirectly migration and immigration, are exponents of the process of rotation. Intensification of the latter two processes is in turn modified by the situation in which the population is placed.

\section{SUMMARY}

In order to trace as accurately as possible the variation in the qualitative composition and the variations in the numbers of small rodents in a defined forest area, the method consisting in intensive capture of the animals living in this area, marking and releasing them and continuing to trace their later life, was used.

Analysis of the frequency of captures made it possible to form an idea of the accuracy of the picture obtained of settlement in the area and its variations in time. It was found that with he same method of capture, trappability differs in the species examined (Fig. 1), and hence the exactitude of the registration of these species differs (Section V). In connection with this, application was made of a different measurement for defining the period of settlement of the individuals in the stidy area, which compensated the difference between the species and was based on the probability of their total capture (Section VI). 
Taking the above as a basis, the sections of length of their stay in the study area were determined for all the individuals, and confirmation was obtained of the data given in earlier studies (Andrzejewski \& Wierzbowska, 1960; 1961 ; A $\mathrm{n}$ drzejewski \& Wroclawek, 1961) as to the exponential character of the distribution of periods of settlement of individuals (Section VI). This made it possible to define the numbers of the group of settled, migrating and pseudomigrating animals and the mean time of settlement of the rodents in the study area in each year of observation (Table 4).

It was shown that the mean time of settlement of males and females is uniform (Table 4).

Assuming the lesser accuracy of the estimate, the number of immigrating, settling, disappearing and settled individuals was defined for consecutive weeks of observation, and also the balance of the numbers of these groups.

On the basis of the above data, calculation was made of the mean numbers of rodents settled in the study area in each month and a description given of the variations in the numbers of each species for the 6-year observation period.

It was found that it is possible to distinguish in the study area at least two per.iods of peak numbers during the yearly cycle: the autumn period, created as a result of the summer-autumn breeding period, and the pre-spring period, probably caused by the immigration of animals from the areas flooded by ground water when the spring thaw sets in (Fig. 5).

The pre-spring increase in numbers breaks up the winter period of reduction in the numbers of these rodents.

Comparison of the dynamics of immigration of the rodents into the study area with the variations in numbers of the settled population made it possible to demonstrate the correlation between the numbers of immigrating and settled animals (Table 7, 8).

A certain part of the individuals immigrating into the study area settle in it permanently. The number of settling animals is in proportion to the number of immigrating animals. This may be the result of 1 . defined participation in the group of animals caught for the first time (immigrating) of individuals which have been settled for some time (Table 4, Section V) and 2. a certain "pressure" of the migrating part of the population on the process of settling in (Section VIII).

In months with a high level of numbers of settled rodents the number of individuals settling is also large. Intensity of settling in relation to the abundance of the settled rodents is low in the winter, then increases to attain its highest level in the autumn (Fig. 8).

The percentage of immigrating animals which then transfer to the settled state does not exhibit considerable variations.

Part of the animals constantly disappear from the group of rodents settled in the study area. The number of disappearing animals is in proportion to the number of immigrating and settling animals in the same time (Table 15, 16, 17, 18), but there are wide divergences from this proportion.

It must be assumed that synchronisation of the processes of settlement and disappearance is caused by variations in the general tendency of these animals to redistribute themselves. Deviations from complete proportionality of these two groups, apart from random deviations, may be caused by the participation in the group of disappearing animals not only of animals passing into a state of migration but also by the death of the settled animals, the intensifications of which are not synchronised with the migration processes. 
During the yearly cycle variations in the intensity of disappearance are slight, and $d$ a reduction in the intensity of disappearance can be observed during the winter $r$ period and also its increase in the late autumn period (Fig. 9).

The constant process of settling and disappearance of the animals in the study $r$ area causes interchange between the individuals settled in it - rotation. The : quantitative intensification of the rotation is in proportion to the number of settled 1 individuals in the study area. Intensfication of rotation (at least in the casc of $f$ C. glareolus) is greater when there are fewer settled individuals in the study area, , and lesser when there are more of these individuals. This may be interpreted as the high degree of settledness of the population being favourable to, or evoking, a more numerous settled population (Andrzejewski \& Wrocławek, 1961), or the high level of numbers of the settled part of the population evoking a reduction in rotation ( $\mathrm{N}$ a u $\mathrm{m}$ o $\mathrm{v}, 1956)$.

The participation of individuals recently settled, and those settled for a considerable time, may vary in the composition of settled individuals. The participation of the latter increases after a period of reduced rotation. This is especially the case during the spring period, in which the number of animals long since settled in the population is greatest after the winter reduction in rotation. It is possible that tinis is favourable to reproducion during this period (Fig. 10).

Significant indices of correlation between immigrating, settling and disappearins individuals are evidence that all these three processes are connected with each other as deriving from the general process of migration of part of the popuiation.

Correlation of intensity of migration with the settled part of the population is evidence that the basic proportions between these groups are maintained, but with wide divergences caused both by the habitat situation (variations during the yearly cycle), and by the population situation (variations in intensity of rotation, higher degree of settlement of $A$. agrarius during the period of mass appearance).

Differences in the height of the indices between $C$. glareolus (lower indices) and A. agrarius (higher indices) indicating the intensity of deviations from: the simple proportion between the migrating and settled parts of the population, may indicate the differences in the ecological situation of these two species.

The characteristics of the population in the given section of the area: the number of settled rodents and their degree of settledness (length of residence) and of the intensity of transit through it of migrants, depends on the processes of inmigration, settlement and disappearance, taking place in the population.

\section{REFERENCES}

1. Andrzejewski, R. \& Pielowski, Z., 1956: Metoda badań ekologicznych nad drobnymi gryzoniami w warunkach leśnych $w$ oparciu o wykorzystaııc przynęty, znakowanie i wypuszczanie złowionych zwierząt. Ekol. pol. B, 2, 3: 209-214, Warszawa.

2. Andrzejewski, R. \& Wi e r z bowska, T., 1960: On the degree of residency and migrancy in populations of small rodents. Bull. Acad. Pol. Sci., Cl. II, 3, 7: 293-300, Warszawa.

3. Andrzejewski, R. \& Wierzbowska, T., 1961: An attempt at assesing the duration of residence of small rodents in a defined forest area and the rate of interchange between individuals. Acta theriol., 5, 12: 153-172, Biłlowieża.

4. Andrzejewski, R. \& Wrocławek, H. 1961: Mass occurence of Apode- 
mus agrarius ( $\mathrm{P}$ a 11 a s, 1771) and variations in the number of associated Muridae. Acta theriol., 5, 13: 173-184, Białowieża.

5. Andrzejewski, R. \& Wroclawek, H., 1962: Settling by small rodents a terrain in which catching out had been performed. Acta theriol., 6, 9: 257-274, Białowieża.

6. Chitty, D. \& Shorten, M., 1946: Technics for study of the Norweg Rat (Rattus norvegicus). J. Mammal., 27.

7. Czyżewski, J., 1953: Zwalczanie szczurów na dużych obszarach. Przeg̣ląd epidem., 7, 4: 277-294.

8. Kalela, O., 1954: Úber den Revierbesitz bei Vögeln und Säugetieren als populations ekologischer Faktor. Ann. Zool. Soc. „Vanamo”, 16, 2: 1-48.

9. L in n, J., 1954: A study based on trapings in west and north Norway. Oikos, 5, 1: $1-77$.

10. (N a u mov, N. P.) Н а у мо в, Н. П., 1951: Новый метод изучения экологии мелких лесных грызунов. Мат. по грызунам 4. Фауна и экология грызунов: $3-21$, Москва.

11. (N a u m ov, N. P.) Н а у м в, Н. П., 1956: Мечение млекопитающих и изучение их внутривидовых связей. Зоол. Журн. 35, 1: 3 - 15: Москва.

12. (N ikitin a, N. А.) Н и к и ин а, Н. А., 1958: Особенности использования территории полевыми мышами (Apodemus agrarius $\mathrm{P}$ all.). Зоол. Журі. 37, 9: 1397 - 1408. Москва.

13. (Nikitin a, N. А.) Н икитина, H. А. 1958 а: Особенности подвижности полевых мышей (Apodemus agrarius Pall.) Бюл. Моск. О-ва Исп. Прир. 63, 4: 13 - 20. Москва.

14. Petrusewicz, K. \& Andrzejewski, R., 1962: Natural history cf a free-living population of house mice (Mus musculus, Linnae us) with particular reference to groupings within the population. Ekol. Pol. 10, 5: 85--122. Warszawa.

15. (Р о u ga у е va, А. G.) Поп уг а в а, А. Г. 1954: Экспериментальные исследования деятельности запасания корма желтогорлой мышю. III Экол. конср., тез. локл. 3: $135-136$. Киев.

16. (R a 11, J. М.) Р а л л, Ю. М., 1936: Характер передвижения мышевидных грызунов на неболыших площадках. Зоол. Журн., 51, 3: $472-482$. Москва

17. Young, H., Strecker, R. L. \& Em len, J. T., 1950: Localization of activity in two indoor populations of house mice Mus musculus. J. Mammal., 31: 403-410 .

Polish Academy of Sciences,

Institute of Ecology,

Warsaw, Nowy Swiat 72.

\section{STRESZCZENIE}

W okresie 6 lat, na powierzchni leśnej wielkości około 3 ha, śledzono dynamikę liczebności, oraz procesy nachodzenia, osiedlania się i ubywania osobników 3 gatunków gryzoni: Clethrionomys glareolus ( $\mathrm{S}$ ch r e be r, 1780), .4podemus agrarius (P a 1las, 1771) i Apodemus (Sylvaemus) flavicollis (MI l c hi or, 1834).

Metodą badań był intensywny połów zwierząt zamieszkujących baduną powierzchnię, znakowanie ich, wypuszczanie i poprzez dalsze polowy śledzenie ich losów. 
Analiza częstości złowień pozwoliła zorientować się w dokładności otrzymy-wianego obrazu zasiedlenia terenu i jego zmian w czasie. Stwierdzono, że przy tej säamej metodzie polowu, łowność $u$ badanych gatunków jest różna (Ryc. 1) i stąd różrna dokładność rejestrowania tych gatunków (rozdz. V). W związku z tym zastosowan.1o, wyrównującą różnicę łowności, inną miarę określenia okresu osiedlania osobnikóíw na powierzchni badań dla poszczególnych gatunków, opartą o prawdopodobieństuwo ich wyłowu (rozdz. VI).

Opierając się na powyższym, ustalono dla wszystkich osobników odciniki czassu przebywania ich na powierzchni badań. W wyniku potwierdzono dane $z$ wcześlnièjszych opracowań (Andrzejewski \& Wierzbowska, 1960, 1961; Andrzcejewski \& Wroclawek, 1961; Petrusewicz \& Andrzejewski, 196s2) o wykładniczości rozkładu czasów osiedlenia osobników (rozdz. VI). Pozwoliło 1to określić liczebność grupy zwierząt osiadłych, migrujących, pseudomigrujących orcaz średni czas osiedlenia zwierząt na powierzchni badań w poszczególnych latach obserrwacji (Tabela 4).

Wykazanc, że średni czas osiedlenia samców i samic jest jednakowy (Tabela 4).

Przyjmując mniejszą dokładność oceny, określono liczbę gryzoni nachodzącycth, osiedlających się, ubywających i osiedlonych dla kolejnych tygodni obserwacji orcaz bilans liczebności tych grup.

W oparciu o powyższe dane wyliczono średnie liczebności gryzoni osiedlonych ma powierzchni badań w poszczególnych miesiącach i opisano dynamikę liczebności pooszczególnych gatunków gryzoni w okresie 6 lat obserwacji.

Stwierdzono, że w cyklu rocznym na terenach badanych daje się wyróżnić przyynajmniej dwa szczyty liczebności: jesienny, powstały $w$ wyniku letnio-jesiennegso okresu rozmnażania i przedwiosenny powstały prawdopodobnie na skutek imigrac jii zwierząt $z$ terenów zalewanych przez wody gruntowe w wyniku roztopów wiosennyc:h (Ryc. 5). Przedwiosenna zwyżka liczebności rozdziela zimowy okres redukcji pogio)wia gryzoni.

Porównanie dynamiki nachodzenia gryzoni na badaną powierzchnię $z$ dynamikia liczebności populacji osiadłej, pozwoliło wykazać korelację między ilościami zwie’rząt nachodzących i osiedlonych (Tabela 7, 8).

Pozwala to przypuszczać, że w głównych zarysach, zmianom liczebności populacjji odpowiadaja proporcjonalne zmiany liczebności zarówno części osiadłej jak i migruijącej. Tym nie mniej średnio wysokie wskaźniki korelacji wskazują na istnienie duıżych odchyleń od tej proporcji. I tak zaobserwowano, że liczba zwierząt nachodzạ:cych jest proporcjonalnie do liczby zwierząt osiedlonych, w okresie zimowym mniej-sza niż w okresie letnim, a szczególnie jesiennym (Ryc. 7).

Pewna cz€́ść osobników nachodzących na badaną powierzchnię stale się na niejj osiedla. Liczba zwierząt osiedlających się jest proporcjonalna do liczby zwierząt na-chodzących. Może to być wynikiem 1) określonego udziału w grupie zwierząt łowio-nych po raz pierwszy (nachodzących) osobników osiedlonych już od jakiegoś czasu (Tabela 4, rozdz. V) i 2) pewnego „ciśnienia” migrującej części populacji na process osiedlania się (rozdz. VIII).

W miesiącach o wysokiej liczebności osobników osiadłych, liczba osobników osiedlających się jest również duża. Nasilenie osiedlania w stosunku do liczebności gryzoni osiadłych jest niskie w zimie, a następnie wzrasta, by w jesieni osiągnąc yoziom najwyższy (Ryc. 8).

Procent zwierząt nachodzących, przechodzących następnie w stan osiadły, nie ivykazuje większych wahań.

Z grupy zwierząt osiedlonych na powierzchni badań stale ubywa część osobników. 
Liczba zwierząt ubywających jest proporcjonalna do liczby zwierząt nachodzących i osiedlających się w tym samym czasie (Tabela 15, 16, 17, 18), jednak od tej proporcji istnieją duże odchylenia.

Należy przypuszczać, że zsynchronizowanie procesów osiedlania się i ubywania jest wywołane zmianami w ogólnej tendencji do przemieszczania się zwierząt. Odchylenia od pełnej proporcjonalności tych dwóch grup, poza odchyleniami przypadkowymi, mogą być wywołane udziałem w grupie zwierząt ubywających nie tylko zwierząt przechodzących w stan migracyjny, lecz także śmiercią zwierząt osiadłych, której nasilenia nie są zsynchronizowane z procesami migracji.

W cyklu rocznym zmiany nasilenia ubywania są niewielkie, obserwujemy zmniejszenie ubywania $w$ okresie zimy i jego wzrost $w$ okresie późno-jesiennym (Ryc. y).

Stały proces osiedlania się i ubywania zwierząt na badanej powierzchni powoduje wymianę na niej osobników osiedlonych - rotację. Ilościowo nasilenie wymiany jest proporcjonalne do liczebności osobników osiadlych na powierzchni badań. Nasilenie rotacji (przynamniej u C. glareolus) jest tym większe im mniej jest osiadłych osobników na powierzchni badań i tym mniejsze im jest ich więcej. Można to interpretować, że wysoka osiadłość populacji sprzyja bądź wywołuje zwiększoną liczebność populacji osiadłej (A ndrzejewski \& Wrocławek, 1961), lub też, że wysoka liczebność części osiadłej wywołuje zmniejszenie rotacji (N a u m o v, 1956).

W składzie osobników osiedlonych może zmieniać się udział osobników niedawno i od dawna w populacji osiadłych. Udział tych ostatnich zwiększa się po okresie zmniejszonej rotacji. Dzieje się tak szczególnie w okresie wiosennym, w którym w populacji liczba zwierząt od dawna osiadłych jest największa po zimowej zniżce rotacji. Możliwe, iż sprzyja to rozrodczości w tym okresie (Ryc. 10).

Istotne wskaźniki korelacji między osobnikami nachodzącymi, osiedlającymi się i ubywającymi świadczą, że wszystkie te trzy procesy są ze sobą powiązane jako pochodne ogólnego procesu migracji części populacji.

Skorelowanie nasilenia migracji z osiadłą częścią populacji świadczy, że zasadni-cze proporcje między tymi grupami są utrzymywane, jednak z poważnymi odchyleniami wywołanymi tak sytuacją środowiskową (zmiany w cyklu rocznym), jak i populacyjną (zmiany nasilenia rotacji, wysokie osiedlenie $A$. agrarius w okresie masowego pojawu).

Różnice w wysokości wskaźników między C. glareolus (wskaźniki niższe) świadczące o nasileniu odchyleń od prostej proporcji między częścią migrującą i osiadłą populacji mogą wskazywać na różnice w sytuacji ekologicznej tych dwóch gatunków.

Charakterystyka populacji na danym wycinku terenu: liczba osobników osiadłych i ich stopień osiadłości (długość ich przebywania) jak i nasilenie przechodzenia przez nią migrantów, zależy od zachodzących w populacji procesów nachodzenia osiedlania i ubywania.

PANSTWOWE WYDAWNICTWO NAUKOWE * WARSZAWA 1963 Nakład 1450 egz. Ark. wyd. 3,5. Maszynopis otrzymano 19.VII.1963. Podpisano do druku 18.XI.1963. Druk ukończono 30.XI.1963. Papier druk. sat. kl. III 80 g. Format B5. Cena $14 \mathrm{z}$.

Bialostockie Zakłady Graficzne. Zam. $2781 *$ A-2. 


\begin{tabular}{c}
\hline BIBLIOTEKA \\
Instytutu Biologii Ssaków \\
Polskiej Akademii Nauk \\
Nr Cz. 40.2 \\
\hline
\end{tabular}

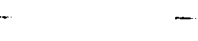

